This item was submitted to Loughborough's Research Repository by the author.

Items in Figshare are protected by copyright, with all rights reserved, unless otherwise indicated.

\title{
Organizational ambidexterity and firm performance: Burning research questions for marketing scholars
}

\section{PLEASE CITE THE PUBLISHED VERSION}

https://doi.org/10.1080/0267257X.2018.1441175

\section{PUBLISHER}

Taylor \& Francis $@$ Westburn Publishers Ltd.

\section{VERSION}

AM (Accepted Manuscript)

\section{PUBLISHER STATEMENT}

This is an Accepted Manuscript of an article published by Taylor \& Francis in Journal of Marketing Management on 26 February 2018, available online:

http://www.tandfonline.com/10.1080/0267257X.2018.1441175.

\section{LICENCE}

CC BY-NC-ND 4.0

\section{REPOSITORY RECORD}

Hughes, Mathew. 2019. "Organizational Ambidexterity and Firm Performance: Burning Research Questions for Marketing Scholars”. figshare. https://hdl.handle.net/2134/28286. 


\title{
Organizational Ambidexterity and Firm Performance: Burning Research Questions for Marketing Scholars
}

\author{
Mathew Hughes \\ Loughborough University \\ School of Business and Economics \\ Loughborough \\ Leicestershire LE11 3TU \\ Tel.: +44 (0)1509 223263 \\ Email: m.hughes2@lboro.ac.uk
}

Acknowledgements: I extend my sincere thanks to JMM Editor Professor Mark Tadajewski for inviting me to write this extensive literature review and critique of organizational ambidexterity, and the research opportunities it poses for marketing and management studies.

This is a preprint of an article whose final and definitive form has been published in the Journal of Marketing Management(C) [2018] [copyrights apply]. The paper is available online at:

http://www.informaworld.com/smpp/

\begin{abstract}
Organizational ambidexterity is an important topic in management research having grown meteorically over the past 17 years. Yet, very few studies in marketing examine organizational ambidexterity. Where studies do exist, seldom do they do justice to its theoretical richness and complexity. This complexity is a significant hurdle for scholars and managers alike, but theory and practice on organizational ambidexterity can benefit substantively from the input of scholars outside the realm of management. This paper provides scholars and managers with a detailed analyses, documentary and corpus of reference material documenting the development, definition, theoretical assumptions and conceptual treatment, measurement and empirical findings to do with organizational ambidexterity. Drawing on this detailed analysis, the paper identifies the burning research questions marketing scholars should give urgent attention to advance theory and practice on organizational ambidexterity.
\end{abstract}

Summary statement of contribution: This paper provides readers with detailed analyses and documentary of the development, definition, theoretical and conceptual treatment, measurement and empirical findings to do with organizational ambidexterity. It identifies the fundamental elements and key assumptions of organizational ambidexterity and reveals implications of conflicts among these elements and assumptions. The paper identifies the burning research questions in need of urgent attention to advance theory and practice.

Keywords: Exploration, exploitation, organizational ambidexterity, literature review

\section{INTRODUCTION}


Organizational ambidexterity is an important and hot topic in management research, having witnessed a meteoric rise in studies since March's seminal work in 1991. Its popularity took hold in the mid-2000s after the empirical work of He and Wong (2004) testing the 'ambidexterity hypothesis'. This hypothesis is deceptively simple: that a firm is rewarded with firm survival and enhanced performance when it achieves a balance of two different activities (exploration and exploitation) that compete with each other. The best firms are those that are ambidextrous, capable of refining and improving current activities to reproduce success (exploitation) while developing completely new activities that instil variety into the firm (exploration) (March, 1991, 2006; Raisch and Birkinshaw, 2008; Tushman and O’Reilly, 1996). However, this simplicity belies considerable implementation challenges. These competing activities require fundamentally different structures, processes and strategies that raise substantial tensions and potential conflict within the firm. March (1991) sees these tensions as largely irreconcilable but predicts that those firms able to manage these tensions and balance the trade-off between exploitation and exploration can secure firm survival and grow firm performance. Those that cannot balance this trade-off face a downward spiral into mediocrity. Tushman and O'Reilly (1996) echo this view, arguing that achieving this balance and level of excellence is very rare. As a consequence, organizational ambidexterity has become something of a holy grail for organizations, the formula for which many theoretical, conceptual and empirical research papers and dedicated special issues have sought to find.

The recipe for organizational ambidexterity and its contribution to firm survival remains elusive. Research into organizational ambidexterity is beset with problems to do with definition, conceptualization, measurement and testing (Birkinshaw and Gupta, 2013; Nosella, Cantarello and Filippini, 2012; Stettner and Lavie, 2014). This is exacerbated by the concept of ambidexterity having been attached to a wide variety of phenomena (Lavie, 
Stettner and Tushman, 2010; O'Reilly and Tushman, 2013) that dilute precision, stretch theoretical prediction and undermine empirical accuracy. Furthering the confusion is its application away from its origins at the firm (or unit) level (Duncan, 1976; March, 1991; Tushman and O'Reilly, 1996) and towards the individual (Birkinshaw and Gibson, 2004; Gibson and Birkinshaw, 2004; Smith and Tushman, 2005) and team (Huang and Cummins, 2011) levels. The relevance of this shift was questioned by Simsek (2009) who argued that implications drawn from these levels of analysis may have little to do with the organization as a whole.

Scholars and managers new to the study of organizational ambidexterity face a complex minefield of issues to navigate and, at the same time, face competing choices in framing and designing their studies. For example, while originally conceptualized as a tradeoff (Duncan, 1976; March, 1991; Tushman and O'Reilly, 1996), others consider exploration and exploitation to be reconcilable (Gibson and Birkinshaw, 2004; Simsek, 2009). This choice fundamentally alters any theoretical and conceptual framing applied to the study of organizational ambidexterity. Reconcilability may also depend on a threshold of firm size (Cao, Gedajlovic and Zhang, 2009). Reasons for these problems are manifold and are to do with clarity over the fundamental elements and key assumptions of organizational ambidexterity, conflicts among these elements and assumptions, and the ways in which organizational ambidexterity has then been conceptualized, measured and tested.

The purpose and contribution of this paper, therefore, are three-fold. First, the paper provides a detailed analysis of organizational ambidexterity, identifying the fundamental elements constituting a rigorous definition and treatment of organizational ambidexterity and forming its theoretical assumptions. The paper offers a conceptual model depicting these theoretical assumptions and illustrates where they compete with each other. It also tackles the problems caused by the various levels of analysis organizational ambidexterity has been 
studied at and what this means for theoretical framing. This provides scholars with a stronger platform for theoretical development.

Second, the forms organizational ambidexterity may take are examined to distinguish between its different conceptualizations and the implications that choice made about its form can have on empirical modelling. Thereafter, problems with current measurement systems used to calculate organizational ambidexterity are scrutinized and the paper directions aligned with the fundamental elements of organizational ambidexterity theory. This provides scholars with a stronger platform for empirical testing.

Third, this paper generates and discusses the burning research questions that are urgent for marketing scholars to answer if they are to advance theory and practice on organizational ambidexterity. Specifically, the paper focuses on those questions that will allow marketing scholars to develop exciting and robust research studies capable of making theoretical and practical contributions to advance our knowledge of organizational ambidexterity. The study of organizational ambidexterity has much to gain from engaging ideas, constructs and theory in the field of marketing. But, marketing scholars must embrace the management theory origins of organizational ambidexterity if they are to develop theoretically robust studies that generate meaningful empirical findings.

Collectively, this analysis contributes to the literature an overdue thorough analytical documentary about organizational ambidexterity. It provides scholars and managers with detailed reference material and a compendium documenting the development, definition, theoretical assumptions and conceptual treatment, measurement and empirical findings to do with organizational ambidexterity. The paper will begin by defining organizational ambidexterity through its theoretical roots in adaptive theory.

\section{DEFINING ORGANIZATIONAL AMBIDEXTERITY}


Before examining the debate surrounding the definition of organizational ambidexterity, the theoretical heritage of organizational ambidexterity in ideas of adaptive systems is presented. This discussion is necessary to understand the origins of the definition and theoretical assumptions of organizational ambidexterity and their evolution over time.

\section{Adaptive Systems and the Theoretical Roots of Ambidexterity}

The idea of organizational ambidexterity originated in the debate about adaptive systemsthe study of organizational adaptation in the face of environmental and technological change (March, 1991; O’Reilly and Tushman, 2013; Tushman and O’Reilly, 1996, 2002). Duncan (1976), believed to be the first to coin the term 'ambidextrous organization' (Simsek, 2009), used it to describe situations in which a firm (or its units) had to establish dual organizational structures to manage the tensions surrounding the initiation and implementation stages of innovation activity. Because firms need to shift structures to initiate and then execute innovation, tensions are created both in the shift itself and in the fact that the necessary structures are themselves very different. It is the firm's ability to manage these tensions that defines its ambidexterity.

Duncan's (1976) work grew from ideas found in the study of organizations (Lawrence and Lorsch, 1967; Woodward, 1965) originating in contingency theory. Contingency theory foresees that organizations will be at their most effective when they are designed to fit the nature of their primary task (an internal perspective) (e.g., Adler, Goldoftas and Levine, 1999) and external environment (e.g., Burns and Stalker, 1961; Lawrence and Lorsch, 1967; Miller and Friesen, 1983). In this literature, different organizational forms are associated with different strategies because of different environmental conditions. A famous illustration of this is Burns and Stalker's (1961) work on mechanistic versus organic structures, in which firms operating in stable environments developed mechanistic structures with clearly-defined 
hierarchies, roles, responsibilities and tasks descriptions, while firms in turbulent environments developed organic structures in which task autonomy, decentralization and a reliance on coordinating across functions were more apparent (see also Mintzberg, 1979). Burns and Stalker's (1961) work sees environmental turbulence as the main contingency factor that determines appropriate forms of organizing. But subsequent works appreciated that, in dynamic contexts at least, young firms and mature firms face fundamentally different structural challenges because their circumstances are not the same (Gilbert, 2005, 2006; Kimberly, 1979; Quinn and Cameron, 1983; Shane, 2003; Sine, Mitsuhashi and Kirsch, 2006).

A plausible conclusion from this body of work is that firms are constantly under tension, a state of duress caused by environmental change both inside and outside the firm. For example, Sine et al. (2006) argued that young firms facing turbulent operating environments frequently need more mechanistic structures to build higher levels of legitimacy, efficiency and responsiveness rather than organic structures (citing Stinchcombe's [1965] arguments about the liabilities of newness in which a lack of structure results in role ambiguity, uncertainty and lack of coordinated action). Organic forms of organizing are needed later to ensure entrepreneurship is not lost (see also Greiner, 1972, 1998). Moreover, periods of environmental and technological change, however rapid, call for firms to adapt and change their structural alignments accordingly (O'Reilly and Tushman, 2013). This underpins the idea that firms must be both efficient and flexible, the so-called "paradox of administration" (Thompson, 1967, p.15) in which managers must balance between structures suited to routine, repetitive tasks and those more suited to nonroutine, innovative tasks (Adler et al., 1999) to survive. This is apparent in Duncan's (1976) original ideas behind the ambidexterity thesis that firms must shift structures as appropriate to originate and implement different forms of innovation. 
This argument brings us back to adaptive systems. In his seminal work, March (1991) argued that environments are changing and incompletely known to the firm and its managers. It is for this reason that March argued that firms must explore new possibilities and exploit old certainties. As such, it was March (1991) that focused the ambidexterity problem onto what is perhaps the most famous trade-off pertaining to ambidexterity: exploitation and exploration. ${ }^{1}$ To appreciate the nature of the ambidexterity problem, an understanding of the challenges posed by exploration and exploitation is needed. Exploration exemplifies search, variation, risk-taking, experimentation, play, flexibility and discovery that create new, disruptive, radical innovations and new product possibilities; but exploitation exemplifies refinement, choice, production, efficiency, selection, implementation and execution intended to better existing product possibilities with incremental innovations (March, 1991.

Exploration requires variation-inducing activities while exploitation relies on variancereducing activities. March (1991) focused the twin tensions of exploration and exploitation onto organizational learning (as a central component of an adaptive system), but implicit to his characterization of exploration and exploitation are ideas of innovation. Tushman and O’Reilly (1996) attached exploration to radical innovation and exploitation to incremental innovation. The comparisons are clear: incremental innovations typically only improve the established technological trajectory, features and processes underpinning products while radical innovations tend to be associated with large, new advances (Kyriakopoulos, Hughes and Hughes, 2016). Their ambidexterity relies on market intelligence derived from responsive versus proactive customer orientations, respectively (Slater, Mohr and Sengupta, 2014). Both March (1991) and Tushman and O’Reilly (1996) assume that exploitation crowds out exploration with its focus on efficiency and execution leading to evermore

\footnotetext{
${ }^{1}$ The tension between exploitation and exploration is the most prominent focus of research on ambidexterity (see Tables 1 and 2 for an illustration as well as the review of Simsek et al., 2009). However, research has broadened the study of ambidexterity to other tensions, a discussion of which can be found in the section entitled, 'The Focus and Subject of Ambidexterity' later in this paper.
} 
incremental innovations. These are attractive because they are low risk and carry relatively certain rewards by adjusting products and activities that have been responsible for the firm's success up to that point in time. But, exploitation is inherently reactive and its actions are at a cost to exploration. Exploration is focused on producing radical innovations that can proactively shape the longer-term future of the firm and can undermine existing products and activities in doing so.

The fundamental adaptive challenge facing firms, then, is the need to exploit its existing assets, resources and capabilities to refine its products, services and processes efficiently, while exploring new technologies, discoveries and ideas to generate new products, services and processes so that the firm is not rendered obsolete by changes in markets and technologies (O'Reilly and Tushman, 2013). It is the balance between exploitation and exploration by which adaptive systems sustain themselves (March, 2006) and it is this balance that defines ambidexterity (March, 1991, 1999). For long-term survival, both exploration and exploitation are needed. In Levinthal and March's (1993, p.105) terms, a firm must "engage in sufficient exploitation to ensure its current viability and, at the same time, devote enough energy to exploration to ensure its future viability". It is the pressures on firms to simultaneously pursue both exploitative (incremental, efficient) and explorative (discontinuous, radical, flexible) innovation activity that creates circumstances calling for the firm to host multiple contradictory structures, processes and cultures within its boundaries (He and Wong, 2004; Tushman and O'Reilly, 1996).

Generally, exploration calls for organic structures and loosely-coupled systems that encourage path-breaking, creative and entrepreneurial firm behaviour commensurate with variance-increasing activities that drive discontinuous innovation associated with creating new products and services; exploitation calls for mechanistic structures and tightly-coupled systems that encourage routinized and stable firm behaviours commensurate with variance- 
reducing activities associated with improving existing products and services. In ambidexterity terms, March (1991) argued that adaptive systems that engage in exploration to the exclusion of exploitation suffer the costs of experimentation without gaining many of its benefits, exhibiting too many undeveloped new ideas, and failing to refine them into workable solutions desired by markets; conversely, systems that engage in exploitation to the exclusion of exploration are likely to become stagnant, relying on past products and formulae in changing competitive, technological and market environments. As a result, "maintaining an appropriate balance between exploration and exploitation is a primary factor in system survival and prosperity" (March, 1991, p.71).

From adaptive theory then, there are two central requirements that underpin organizational ambidexterity. First, a firm must be able to replicate success and reproduce the attributes behind that success more reliably than its competitions; second, a firm must generate variety by creating the conditions for opportunities to experiment with new possibilities (March, 2006). The parallels to exploitation and exploration are readily apparent: the former involves improving and reapplying established capabilities and practices to problems as it yields reliable, standard, predictable outcomes; the latter involves novel, unconventional and less-predictable actions (March, 2006). This further parallels the tension between exploration and exploitation: because the returns to exploration are more unpredictable, distant and uncertain, firms tend to favour exploitation owing to the greater certainty of its rewards (March, 1991). Stated differently, ideas generated through exploration become "the bases for major innovations and responses to change when they prove to be right; they can lead to major disasters when they prove to be wrong” (March, 2006, p.205). For these reasons, when environments are changing and incompletely known, successful adaptation requires firms to exhibit both exploitation and exploration for persistent success. It is the latter that is most elusive (March, 2006). 
The elusiveness of exploration also has its origins in the nature of organizational learning. Organizational learning is typically driven by a rational search process (March, 2006). Rational searching tends to be local and focused on the object of the firm's current operations. This form of organizational learning is self-reinforcing in nature (Levinthal and March, 1993; March, 1991) and driven by a rational logic in which firms seek to become 'more intelligent' (March, 2006). This lends itself to a focus on adapting to the existing environment, which increases the danger of structural inertia (Hannan and Freeman, 1984) and turns capabilities into rigidities (Leonard-Barton, 1992), exacerbating constraints to a firm's capacity to adapt to future environmental changes, and recognise or shape (proactively) future markets and advance on new opportunities (Levitt and March, 1988; Rosenkopf and Nerkar, 2001), whether these opportunities are discovered or created (Alvarez, Barney and Anderson, 2012). But excessive exploration can be just as destructive with its failures triggering yet more search and change (Levinthal and March, 1993) until resources are depleted (by which time the likely outcome is a switch to exploitation, e.g., Voss, Sirdeshmukh and Voss, 2008).

The 'ambidexterity hypothesis' (He and Wong, 2004) postulates that those firms that achieve a balance of exploration and exploitation achieve performance advantages that outstrip rivals lumbered with excessive experimentation or excessive refinement. With this understanding of the theoretical background of organizational ambidexterity, the paper now moves to discuss its definition and alternative characterizations of organizational ambidexterity in the literature to date.

\section{Definitions and Fundamental Elements of Organizational Ambidexterity}

Table 1 presents a series of definitions attributed to organizational ambidexterity from its origins in Duncan's work in 1976 up to recent times among organization and management 
studies (its home literature). The purpose of this analysis is not to form another new definition of organizational ambidexterity. Rather, its purpose is to identify and describe the recurring fundamental elements found among existing definitions of organizational ambidexterity in management and organization studies so that marketing scholars can carry out a more comprehensive and informed analysis of it. This is important because it helps overcome the "generic use" of the term organizational ambidexterity as a simple reference to the ability of a firm to do two things simultaneously (O'Reilly and Tushman, 2013, p.329). In addition, it will aid researchers to apply the term to phenomena that are directly tied to the tensions in ensuring firm survival (O'Reilly and Tushman, 2013) with greater accuracy and greater appreciation of its core theoretical assumptions. Six fundamental recurring elements are identified: (1) simultaneity versus punctuation, (2) trade-off and balance, (3) synchronicity and dexterity, (4) magnitude, (5) managing tension, and (6) firm survival.

\section{[INSERT TABLE 1 ABOUT HERE]}

\section{Simultaneity versus Punctuation}

The most apparent and recurring theme among definitions of organizational ambidexterity is simultaneity. While not directly specified in Duncan's original (1976) use of organizational ambidexterity, the idea of simultaneity is repeatedly found across the majority of its definitions. For example, Tushman and O'Reilly (1996, p.24) described it as "the ability to simultaneously pursue both incremental and discontinuous innovation”, Adler et al. (1999, p.45) defined it as "the challenge of simultaneously performing both routine and nonroutine tasks", Gibson and Birkinshaw (2004, p.209) characterize it as "the behavioral capacity to simultaneously demonstrate alignment and adaptability across an entire business unit", with Jansen et al. (2006, p.1661) labelling ambidextrous organizations as those that "develop 
exploratory and exploitative innovation simultaneously in different organizational units", and Raisch and Birkinshaw (2008, p.375) saw successful firms as ambidextrous when "aligned and efficient in their management of today's business demands while simultaneously adaptive to changes in the environment."

Nevertheless, while the idea of organizational ambidexterity as simultaneously managing two competing activities is a recurring theme, Gupta, Smith and Shalley (2006) suggest that firms may cycle or iterate between periods of exploration and exploitation instead. They describe this as a punctuated equilibrium view of ambidexterity. The separation is temporal as opposed to structural (cf. Duncan, 1976; Tushman and O'Reilly, 1996). For the most part, this view is not reflected in any other definition of ambidexterity. But the idea of temporal cycling is interesting because it places even greater complexity on the firm to create circumstances and conditions within its boundaries that enable the shift from one very different activity to another.

The main concern with the punctuated equilibrium view is, given that exploitation is self-reinforcing and replicates actions and systems befitting to it (as can excessive exploration; see Levinthal and March, 1993), how might a firm become sensitized to the point at which the shift is needed (before it is too late) and for the shift to be made in a way that achieves the right standard? Levinthal and March (1993, p.98) suggest that the shift might be a function of "the sequential allocation of attention to divergent goals" (emphasis added), which is important in the light of works using the attention-based view of the firm to explain how activities and their resourcing divert attention towards or away from explorative or exploitative activities and their balance (Kyriakopoulos et al., 2016; Ocasio, 1997; Voss et al., 2008). A further explanation can be sourced from punctuated equilibrium theory itself (Gersick, 1991; Miller and Friesen, 1980, 1984; Tushman and Romanelli, 1985). Under this theory, organizational transformation is the main object of interest and predicts a firm as 
going through an equilibrium phase for a certain period of time, before a transformation then occurs due to external and internal factors acting on the firm, and before it again returns to a stable state for an (undefined) period of time. If exploitation represents that stable state, moving the firm into an unstable state requires more than mere external pressure since the systems used for exploitation create substantial inertia to change.

\section{Trade-off and Balance}

As features of a definition of organizational ambidexterity then, simultaneity and punctuated equilibrium cannot co-exist. The decision on which one a research study ultimately adopts depends on its theoretical lens. But, while presenting very different views of how organizational ambidexterity might be organized, simultaneity and punctuated equilibrium do share a common characteristic in defining ambidexterity: the idea of trade-off. March's (1991) seminal work is adamant that exploration and exploitation compete for scarce resources and require such fundamentally different demands of the firm that they are irreconcilable, presenting a trade-off that requires balance. This is apparent in the adaptive theory origins of organizational ambidexterity as well. The actual term 'balance' does not repeat itself in many definitions of organizational ambidexterity among organization and management studies (for notable exceptions, see He and Wong [2004] and their citation to Tushman and O'Reilly, 1996) but it forms a crucial part of how ambidexterity is regarded theoretically and operationally. Cao et al. (2009) present a treatment of this matter, separating organizational ambidexterity into two dimensions, a 'balance' dimension that acknowledges March's trade-off and a 'combined' dimension, intended to capture the magnitude of both exploration and exploitation. Cao et al. (2009) see these two dimensions as conceptually distinct and relying on different mechanisms through which to affect firm performance. These authors find that the balance dimension is more rewarding for resource-constrained 
firms whereas the combined dimension is more rewarding for those firms capable of accessing a wealth of internal and/or external resources. At the very least this points towards context as an important aspect of how scholars visualise the matter of balance in organizational ambidexterity, and whether that balance always contains a trade-off or not.

\section{Synchronicity and Dexterity}

A different characterization of simultaneity relevant to this discussion is the idea of synchronicity. Gupta et al. (2006, p.693) define organizational ambidexterity as "the synchronous pursuit of both exploration and exploitation via loosely coupled and differentiated subunits or individuals, each of which specializes in either exploration or exploitation." At first glance, synchronicity may appear to be the same as simultaneity but there is a subtle difference. Synchronous means existing and not just operating at the same time. This is very important because a key feature of the theoretical debate led by March (1991) (and very apparent in the work of Tushman and O'Reilly, 1996) is that the organizational ambidexterity of exploration and exploitation is based on a trade-off. Gupta et al. (2006), Birkinshaw and Gibson (2004) and Gibson and Birkinshaw (2004) do not restrict organizational ambidexterity to a trade-off, suggesting the two are reconcilable instead (although Birkinshaw and Gupta, 2013, p.291, later point back towards an inherent incompatibility being a feature of ambidexterity). Some empirical evidence exists about their complementarity (e.g., Bierly and Daly, 2007; cf. Stadler, Rajwani and Karaba, 2014) and the possibility that they interact in non-destructive ways (He and Wong, 2004), but the theoretical basis for such an empirical observation is (at best) underdeveloped (see Knott, 2002, as one proponent of the complementarity view). An anomaly also exists in Lubatkin et al.'s (2006, p.647) definition of organizational ambidexterity, which speaks of exploiting and exploring "with equal dexterity" (emphasis added) (see also Simsek, 2009). This is important 
because it is one of the few definitions that specifically indicate a qualitative element to the performance of exploration and exploitation.

Dexterity implies skilfulness suggesting that both exploration and exploitation should be strong. This, inadvertently at least, appears to compete with a trade-off idea whereby the challenges each pose might complicate both from being or becoming very high within a single firm boundary. Bierly and Daly (2007, p.497) use similar verbiage, describing organizational ambidexterity as "simultaneously excelling at exploration and exploitation" (emphasis added). Andriopoulos and Lewis (2009, p.696) also define ambidextrous organizations from the point of view of firms that "excel at exploiting existing products to enable incremental innovation and at exploring new opportunities to foster more radical innovation." Nevertheless, these authors also acknowledge in their definition that "[yet] tensions emanate from their different knowledge management processes... [and]... [o]rganizational ambidexterity signifies a firm's ability to manage these tensions" (p.696). This raises a question as to whether the ambidextrous state is, therefore, an ideal state or not as firms lose out on specialization if exploration and exploitation are indeed a trade-off.

\section{Magnitude}

The ideal state ambidexterity should take is undecided, and this matter is clouded by the arguments presented by Nosella et al. (2012). Citing O’Reilly and Tushman (2004, 2008), these authors argued that "succeeding in simultaneously accomplishing high levels of both the poles causing such tensions [having to deal with contrasting and conflicting goals] are essential to firms' competitiveness and survival" (Nosella et al., 2012, p.450, emphasis added). This speaks to both the balance and combined dimensions as conceptualized by Cao et al. (2009) and thus point towards magnitude as a feature of the definition of organizational ambidexterity. Yet, Tushman and O'Reilly (1996) suggested that in practice few firms may 
actually succeed in establishing or managing organizational ambidexterity because exploration and exploitation represent fundamentally different logics calling for different structures, strategies and behaviours. To these authors, it is more a question of managing the tension surrounding the irreconcilability of competing goals (or activities), and implicit in their argument is that the failure to manage these tensions sufficiently well enough might result in the firm being worse off rather than better off (He and Wong, 2004).

\section{Managing Tension}

Whether efforts to achieve competing goals or activities are reconcilable or not, there is no escaping that managing tension is a fundamental aspect of ambidexterity and ambidexterity ultimately represents the ability of the firm to manage those tensions (Andriopoulos and Lewis, 2009; Nosella et al., 2012). Unlike other definitions, Nosella et al. (2012, p.450) suggest that organizational ambidexterity in light of this need to manage tension is a capability, expressing that "organizations able to [manage tensions as well as succeeding in simultaneously accomplishing high levels of both the poles causing such tensions] possess the ambidexterity capability, namely the capability of a complex and adaptive system to achieve and manage conflicting activities, by realizing high levels of both in a simultaneous way." Just as interesting is their argument that, "[the] organizational ambidexterity literature had departed from the original definition of the construct as a capability for resolving tension" (p.459). Analysis of the 17 definitions among organization and management studies does not expressly identify a reference to capability apart from Nosella et al. (2012), although some (e.g., Andriopoulos and Lewis, 2009; Duncan, 1976; Junni et al., 2013; Tushman and O’Reilly, 1996) do refer to an 'ability' to manage competing activities simultaneously. Further light is shed by O'Reilly and Tushman $(2008,2013)$ who suggest that ambidexterity is about "developing the capabilities necessary to compete in new markets and technologies 
that enable the firm to survive in the face of changed market conditions" (O'Reilly and Tushman, 2013, p.330). The fact that capability is plural in this statement suggests that ambidexterity is an antecedent to some other capabilities necessary to compete effectively. For now, this matter seems to be unresolved, but for scholars it indicates a need to consider very carefully any theoretical lens they attach to the study of ambidexterity and whether that evokes a need to present ambidexterity as a capability or as a state, for example.

An overlooked theoretical lens pertinent to managing tension is dialectical theory. ${ }^{2}$ Dialectical theory assumes that a firm exists in a pluralistic world in which events, forces or values collide, contradict or compete with each other for domination or control (Van de Ven and Poole, 1995). Within the context of internal organizational phenomena, dialectical forces compete for scarce resources and managerial attention and undermine competing organizational features (de Rond and Bouchikhi, 2004). This theory is relevant to examining organizational ambidexterity since the goals, interests and activities associated with exploration and exploitation conflict and compete for priority. However, this position only holds if we accept the assumption that the two activities are a trade-off in need of balance. It does not hold if we take the counter-assumption that the two are reconcilable. Dialectical theory further assumes a new organizational form (or arrangement) will emerge to resolve the conflict (Benson, 1977). This arrangement can be thought of as the form organizational ambidexterity takes to resolve the tension. These may be structural (Duncan, 1976; Tushman and O'Reilly, 1996), contextual (Gibson and Birkinshaw, 2004), or punctuated or cyclical (temporal) iteration between periods or episodes of exploration and exploitation (Gupta et al., 2006). The form organizational ambidexterity may take is a non-trivial problem examined at length in the section, 'Forms of Ambidexterity'.

\footnotetext{
${ }^{2}$ I thank an anonymous reviewer for this valuable suggestion.
} 


\section{Firm Survival}

The final fundamental element of organizational ambidexterity is a firm survival element versus a performance-enhancing element. March (1991) is explicit that balancing exploration and exploitation is necessary for firm survival (see also Levinthal and March, 1993; Nosella et al., 2012). O'Reilly and Tushman $(2008,2013)$ are similarly minded, specifying that "the long-term survival of the firm is the sine qua non of organizational ambidexterity" (2013, p.330). Gupta et al. (2006) are more ambiguous on this matter, arguing that a plausible case exists for specialization as a viable alternative route to long-term survival if the trade-off between exploration and exploitation is insurmountable. For example, the market could provide the firm with the missing activity to achieve a 'balance' (Gupta et al., 2006). Benner and Tushman (2003) also accepted the possibility of specialization, noting that their propositions about firms adopting both exploration and exploitation innovation strategies may not generalize to those firms that specialize. A comparative study remains elusive but the answer may lie in March's (1999) own critique that balance is something that is very difficult to achieve and failure to achieve that balance correctly may even undermine the firm (see also He and Wong, 2004; Tushman and O'Reilly, 1996).

Generally, the direction of evidence in the literature is that achieving organizational ambidexterity appears to be performance enhancing, but it is not a binary or simple equation (e.g., Cao et al., 2009; Junni et al., 2013; O'Reilly and Tushman, 2013). This matter is addressed in a later section in this paper titled, 'Organizational Ambidexterity and Firm Performance'. From a definitional point of view, Cao et al. (2009) point to a performanceenhancing element in their definition of organizational ambidexterity but caution is warranted here: a definition of ambidexterity should not introduce a theoretical assumption that renders ambidexterity a tautology. 
From this analysis, six fundamental elements underpin a definition of organizational ambidexterity: (1) simultaneity versus punctuation, (2) trade-off and balance, (3) synchronicity and dexterity, (4) magnitude, (5) managing tension, and (6) firm survival. These six fundamental elements set the theoretical assumptions for causal relationships to do with organizational ambidexterity. These fundamental components and their associated theoretical assumptions are illustrated in Figure 1. Figure 1 provides a conceptual model of organizational ambidexterity in the form of a flow diagram that iteratively reveals its theoretical assumptions depending on what start point the researcher takes on the nature of ambidexterity (e.g., whether it is based on trade-off, contextual balance, dexterity or punctuation). The subsequent theoretical assumptions associated with each view of organizational ambidexterity are mapped to provide a clear basis for future theoretical framing and empirical modelling endeavour.

\section{[INSERT FIGURE 1 ABOUT HERE]}

Next, the paper moves to examine the treatment of organizational ambidexterity among marketing-related studies, juxtaposing marketing's treatment of organizational ambidexterity versus the principles established in its home literature in management to determine the extent to which marketing scholars have treated these six fundamental elements and accurately represented the assumptions underpinning organizational ambidexterity theory.

\section{Treatment of Organizational Ambidexterity in Marketing}

Table 2 presents treatments of organizational ambidexterity in marketing-related studies. Only a few studies of organizational ambidexterity in the field of marketing exist, which is 
surprising given how exploration and exploitation speak closely to ideas of radical and incremental innovation (Tushman and O'Reilly, 1996), and ideas about 'aligning with the customer needs of today while adapting for the needs of tomorrow' (Gibson and Birkinshaw, 2004) evoke marketing imagery. There are only some similarities in how marketing-related studies have treated organizational ambidexterity to their counterparts in organization and management studies, and important disparities exist. This section will evaluate the extent to which marketing has sufficiently treated the fundamental elements and associated theoretical assumptions of organizational ambidexterity.

\section{[INSERT TABLE 2 ABOUT HERE]}

Simultaneity is a persistent feature (e.g., Atuahene-Gima, 2005; Cegarra-Navarro and Dewhurst, 2007; Hughes et al., 2010; Judge and Blocker, 2008; Menguc and Auh, 2008) but no reference is made to the counter idea of punctuation. Still, there are subtleties that suggest inadequate theoretical treatment of organizational ambidexterity among marketing studies. For example, Swart and Kinnie (2007) referred to exploration and exploitation as taking place “concurrently" within "accelerated/short-term and planned/longer-term time frames" (p.339), Morgan and Berthon (2008, p.1329) refer to the "ambidextrous association" between exploration and exploitation and Vorhies et al. (2011) speak of combining exploration and exploitation, but these studies do not directly specify the nature of the combination. This is compounded by little theoretical clarity about the notions of trade-off and balance. Thus, theoretical and predictive apparatus among marketing studies of organizational ambidexterity fail to address the conundrum at the heart of simultaneity: will a firm have to trade-off and achieve a balance of exploration and exploitation to avert risks to firm survival (assumption A), or will a firm have to achieve and coordinate high dexterity across both dimensions to 
avert risks to firm survival (assumption B or C)? These assumptions lead to fundamentally different conceptual models and causal predictions, and carry very different measurements needs.

There are specific contradictions among marketing studies about the idea of trade-off versus complementarity from the point of view of balance. For example, Prange and Schlegelmilch (2009, p.217) define organizational ambidexterity as "to balance the dual processes of exploration and exploitation... a conceptual framework for implementing inherently contradictory [explorative and exploitative] marketing strategies.” Their emphasis on exploration and exploitation being "inherently contradictory" speaks to the idea of tradeoff. Kyriakopoulos and Moorman (2004) similarly make reference to Levinthal and March's (1993) work, which addresses the conflicting trade-off between exploration and exploitation such that a precise mix is needed to achieve balance. From there on, problems are apparent. For example, Morgan and Berthon's (2008, p.1329) description of an “ambidextrous association" introduces a degree of doubt about whether exploration and exploitation are in conflict or not; Menguc and Auh (2008) highlight organizational ambidexterity as requiring the combination of exploration and exploitation as "discrete" activities but the manner of the competition between the two activities is left untreated; and Cegarra-Navarro and Dewhurst (2007) treat organizational ambidexterity as an organization's context to achieve alignment and adaptability simultaneously (which replicates the counter-perspective of Gibson and Birkinshaw, 2004, from management studies, which suggests reconcilability). Marketing scholars, then, have not properly theorized the fundamental competition-conflict problem at the heart of organizational ambidexterity on a regular basis.

Work by Yalcinkaya et al. (2007) directly contradicts the trade-off idea, with predictions that are almost antithetical to organizational ambidexterity theory. Yalcinkaya et al. (2007) gave no clear definition of ambidexterity but predicted, and found supporting 
evidence for, exploitation being positively related to exploration, which is entirely incompatible with March's (1991) thesis and trade-off arguments. While potentially compatible with Gupta et al.'s (2006) orthogonality arguments, Yalcinkaya et al. (2007) argue that instead of competing or being complementary, exploitation augments exploration. Given that exploitation calls for fundamentally different systems, activities and behaviours compared to the ones needed for exploration, and compete for resources, the theoretical basis for such a hypothesis is highly questionable. In contrast, Vorhies et al. (2001) specify that firms must strike a complementary balance between exploration and exploitation. Yet, like Yalcinkaya et al. (2007), Vorhies et al. (2011) do not test ambidexterity in and of itself. Instead, they predict that (marketing) exploitation will negatively moderate the effect of (marketing) exploration on customer-focused marketing capabilities and vice-versa (hypotheses 5a and 5b). These authors acknowledge a need for balance (p.737; pp.742-743) yet their conceptual treatment does not align with this theorization. Their results do find support for negative moderation effects that in turn indicate a tension, but their empirical model is incomplete as it does not then test the effects of organizational ambidexterity having postulated and evidenced such a problem.

From the six fundamental elements of organizational ambidexterity theory, marketing has so far only treated 3 of those conditions (and only simultaneity with any regularity) and has treated the ideas of trade-off and balance in ways that are at times antithetical to the ambidexterity thesis. The relative infancy of organizational ambidexterity to the marketing field may explain why sophisticated elements such as synchronicity and dexterity, magnitude and managing tension have remained untreated to date. However, it does not explain why critical theoretical assumptions to do with balance and trade-off have been only partially treated. Inadequate theoretical treatment and poor conceptualization of ambidexterity among marketing studies must be rectified by marketing scholars to avoid problems that risk 
invalidating their works and jeopardizing the accumulation of accurate knowledge about organizational ambidexterity. Greater attention to the six fundamental elements of organizational ambidexterity is needed to sufficiently treat it among future studies, and particularly to ensure that valid theoretical predictions are made. This is necessary to prevent false assumptions but also to make clear how propositions and hypotheses are arrived at. Otherwise, a legitimate question is raised as to whether reported relationships are truly viable or some kind of artefact representing a Type I statistical error.

Emerging from the analysis the fundamental elements and theoretical assumptions of organizational ambidexterity theory is the matter of the form that ambidexterity can take to resolve the tensions contained within the theory. This is a fundamental matter because depending on what elements of a definition are adopted, the theoretical assumptions the research will then make determines which form that organizational ambidexterity must take. This is addressed next.

\section{FORMS OF AMBIDEXTERITY}

The paradox of exploration and exploitation is that exploitation creates the income needed to fund future exploration and exploration itself creates the opportunities for future exploitation (Lavie et al., 2010). The object of interest then becomes the 'form' of that ambidexterity or the action that can be taken to relax the tension between exploration and exploitation, of which there is considerable debate in the literature.

Organizational ambidexterity can be summarized in relatively simple terms as the state of attaining exploration and exploitation with some kind of skilfulness, adroitness or agility in doing so. March (1991) and Tushman and O'Reilly (1996) are adamant that these activities present such competition to each other that they represent an irreconcilable tradeoff. The alternative is whether the two activities are in fact independent (Gupta et al., 2006), 
and capable of being reconciled within the firm (Gibson and Birkinshaw, 2004), such that the firm can achieve high levels of both exploration and exploitation (Simsek, 2009; Simsek et al., 2009). From this debate have emerged ideas of 'structural ambidexterity' (Tushman and O’Reilly, 1996; Jansen et al., 2006), ‘contextual ambidexterity' (Gibson and Birkinshaw, 2004) (sometimes known as 'behavioural ambidexterity', Simsek, 2009), 'temporal ambidexterity' (Gupta et al., 2006) and specialization, or 'domain ambidexterity', a very recent form of ambidexterity in which a firm may specialize in either exploration or exploitation but obtain the other through relationships, for example. A description of each form is detailed in Table $3 .^{3}$

\section{[INSERT TABLE 3 ABOUT HERE]}

There is no single correct answer to this conundrum. For example, Simsek (2009) and Simsek et al. (2009) acknowledge the trade-off between exploration and exploitation inherent to the tension in organizational ambidexterity but insist that this trade-off is a starting point from which successful firms try to attain high level of both exploration and exploitation (cf. March, 1991, 1999) (or what Simsek, 2009, described as 'dexterity'). The resource intensity of this endeavour alone is problematic to firms let alone the sheer implementation challenges it implies (Stettner and Lavie, 2014). But it also overlooks a different line of argument: a balance dimension of ambidexterity (BD) and a combined dimension of ambidexterity (CD) make different contributions to firm performance depending on the resource limitations of the firm (Cao et al., 2009). Cao et al. (2009) find that BD is more beneficial to resource-

\footnotetext{
${ }^{3}$ The organizational ambidexterity literature has, at times, been its own worst enemy. For example, Simsek et al. (2009) used different labels to form constructs that are ultimately the same as (or are very similar to) existing ones, e.g., structural ambidexterity was replaced by 'partitional ambidexterity', contextual ambidexterity was replaced by 'harmonic ambidexterity', and temporal ambidexterity was replaced by 'cyclical ambidexterity' and 'reciprocal ambidexterity'. For consistency, and to prevent conceptual confusion, I will only use the original terms in this paper.
} 
constrained firms while CD is more beneficial to firms having greater access to internal and/or external resources. They conclude that, "managers in resource-constrained contexts may benefit from a focus on managing trade-offs between exploration and exploitation demands, but for firms that have access to sufficient resources, the simultaneous pursuit of exploration and exploitation is both possible and desirable" (Cao et al., 2009, p.781).

Resource limitations speak to matters of firm size. There are very few studies of SMEs, for example, in treatments of organizational ambidexterity (as notable exceptions see Chang and Hughes, 2012; Hughes et al., 2010; Lubatkin et al., 2006; Voss and Voss, 2013; Voss et al., 2008). Because March's original (1991) thesis argued for the irreconcilability of exploration and exploitation and so a need for 'balance', subsequent studies focused very quickly on structural solutions (structural ambidexterity) in which exploration and exploitation (as the two competing and irreconcilable activities) are structurally separated into their own units to be coordinated by various mechanisms (Benner and Tushman, 2003; Cao et al., 2009; Jansen et al., 2006; Jansen, Tempelaar, Van den Bosch and Volberda, 2009; Tushman and O'Reilly, 1996). Entirely distinct structures and processes are to be expected as well as separate management teams and incentive systems (O'Reilly and Tushman, 2008; Taylor and Helfat, 2009; Tushman and O'Reilly, 1996).

However, such a structural solution suits large firms but not small firms (Chang and Hughes, 2012; Chang, Hughes and Hotho, 2011), which are resource constrained. Simsek (2009) and Simsek et al. (2009) neglected the resource absorption consequences of exploration, exploitation and ambidexterity when arguing that both exploration and exploitation should be high. For example, Voss et al. (2008) found that SMEs lacking slack resources tend to prioritize exploitation as a result. This is a necessary course of action to make the best use of scarce resources instead of risking them on exploratory efforts whose returns are neither certain nor immediate enough to ensure financial sustainability in the 
short-to-medium term. But, when slack resources are introduced or become available, Voss et al. (2008) found that SMEs tended to divert attention towards exploration at a cost to exploitation. This suggests that resources matter, and so does context. From the point of view of adaptive theory (March, 1999), the SME must reproduce the conditions underpinning short-to-medium term success but its ability to generate variety is constrained by resource (un)availability.

The alternative to structural separation is contextual ambidexterity. The theoretical treatment of contextual ambidexterity assumes that exploration and exploitation can be reconciled within a subsystem, firm or business unit (Adler et al., 1999; Gibson and Birkinshaw, 2004), and is more favourable when firms are smaller in size or face larger resources constraints (Chang and Hughes, 2012; Chang et al., 2011). Contextual ambidexterity still assumes simultaneity, but believes that through the proper design of organizational structure, culture and routines, both exploration and exploitation can be set in place and be made effective without the need to structurally separate (see Adler et al., 1999; Birkinshaw and Gibson, 2004; Gibson and Birkinshaw, 2004). Toyota is an example of a company in which exploration and exploitation have co-existed for decades (Knott, 2002; Takeuchi, Osono and Shimizu, 2008). Exploration and exploitation are then distinct, not competing, activities that should be pursued fully and simultaneously to achieve firm performance, a competitive advantage and secure the survival of the firm (He and Wong, 2004; Gibson and Birkinshaw, 2004; Simsek et al., 2009).

Both structural and contextual ambidexterity, however, omit time as a component of the ambidexterity problem. Gupta et al. (2006) argued that because ambidexterity refers to the synchronous pursuit of exploration and exploitation through loosely-coupled and differentiated subunits that each specialize individually in either exploration or exploitation (a structural perspective), temporal cycling might be a more viable option than their 
simultaneous pursuit. Temporal ambidexterity sees the firm cycle between longer periods of exploitation and shorter periods of exploration as required by the needs of the firm or unit over time (Gupta et al., 2006; Lant and Mezias, 1992; Romanelli and Tushman, 1994). This sequential pursuit might alleviate some of the resource and administrative challenges associated with the simultaneous approach (Gupta et al., 2006; Simsek et al., 2009), but the challenges it holds for implementation have received little thought. The main challenge is to proactively manage the transition between exploitation and exploration (Siggelkow and Levinthal, 2003) with efficient procedures (Eisenhardt and Brown, 1997), enabling the firm to shift from one activity to another over time (Duncan, 1976) and to do so in a way that does not incur the conflict and tension between exploration and exploitation (Lavie and Rosenkopf, 2006). Yet, such implementation is fraught with difficulty not least due to the reinforcing path dependence of each activity over time, raising the spectre of delay, significant cost, and a failure to achieve either activity to a sufficiently high standard.

From an implementation point of view, each form of organizational ambidexterity has a different organizing principle. Kang and Snell (2009) describe structural ambidexterity as 'partitioning', largely because they focus on 'ambidextrous learning' and so the structural terminology might not make sense therein. Nevertheless, the idea of partitioning is still the same as structural ambidexterity—units engaged in exploratory learning are physically separated from those emphasizing exploitation and managerial capabilities should then be used to coordinate the two. This is spatial partitioning. Kang and Snell (2009) also refer to temporal partitioning, a phenomenon that occurs when exploration and exploitation are separated by time. This bears similarity to the punctuated equilibrium argument of Gupta et al. (2006), and the organizing principle is then one of managing sequential movement and iteration in the transition. However, Kang and Snell (2009) do not attend to the demands and challenges posed by shifting the emphasis in such dramatic ways and ensuring in doing so 
that the standard of either exploration or exploitation or both is somehow made 'high'. While acknowledging that either spatial or temporal partitioning raise (unanswered) questions about how firms make a smooth transition between exploration and exploitation, their solution remains incomplete (a call for managerial meta-capabilities and temporal decentralization is made, two different architectures [organic versus mechanistic] are suggested and indications are made to the role of functions such as HRM, but ultimately these speak largely to spatial partitioning and not temporal partitioning).

As an alternative to partitioning, Kang and Snell (2009) suggest 'ambidextrous learning' as an option, which is worded similar to Gibson and Birkinshaw's (2004) contextual ambidexterity, "in which a firm can establish a continuous process of exploitation and exploration by establishing [an] organization[al] context that enables and encourages every individual in the organization to allocate his or her time and effort to look for new knowledge and/or configure new combinatory mechanisms, and concurrently cultivate or streamline new value-creating ideas. This approach requires the collective orientation of individuals towards dual capacities, rather than a higher-level separation or partitioning of those capacities (Gibson and Birkinshaw, 2004)" (Kang and Snell, 2009, p.73, emphasis added). The organizing principle is then the internal environment of the firm. Gibson and Birkinshaw (2004) and Kang and Snell (2009) make an untested assumption that this approach helps to avoid potential coordination problems and costs vis-à-vis structural ambidexterity/partitioning. But this is a risky assumption. For example, the idea that "every individual in the organization" is involved in both exploration and exploitation implies that organization-wide exploration and exploitation is inherently sensible or needed. Can, or should, everyone across all different departments and functions in a firm really carry out ambidextrous actions and not have any kind of coordination problem or cost? This is highly 
unlikely and suggests that aggregating the matter of ambidexterity entirely to the firm level is not without its problems.

The literature on the execution of organizational ambidexterity across a firm has been subject to scathing criticism for its inability to provide guidance in the face of serious and non-trivial implementation challenges (Nosella et al., 2012; Stettner and Lavie, 2014). Structural separation appears to be the most 'straightforward' solution, but Birkinshaw and Gupta (2013) debunk this idea, arguing that even units such as R\&D typically associated with exploration must link the ideas they generate back to the existing resources and activities of the firm, and units responsible for exploitation such as manufacturing will also encounter instances where repetitious, efficiency-oriented work must be advanced through process innovation (e.g., Hill and Birkinshaw, 2014). This debate raises very important questions about the level of analysis and implies that functions might play an important role in resolving the ambidexterity dilemma.

Birkinshaw and Gupta (2013) suggest that organizational ambidexterity may be a nested concept, transpiring at multiple levels in the firm due to organizations being 'nearly decomposable systems' (Simon, 1962) ${ }^{4}$. 'Nearly' here refers to the fact that each part or function of the firm still rely on some reference to another (or several others) and speaks to suggestions that ambidexterity is a multilevel matter (Jansen, Simsek and Cao, 2012; Simsek, 2009). An alternative perspective is that a firm's ability to manage exploration and exploitation simultaneously is achieved through multiple modes of organizing (Stettner and Lavie, 2014) including using specializations that reside within, outside and across the firm's boundaries (Gupta et al., 2006; Kauppila, 2010; Lavie and Rosenkopf, 2006; Lavie et al.,

\footnotetext{
${ }^{4}$ Birkinshaw and Gupta (2013) suggested that organizational ambidexterity transpires at multiple levels in the firm simultaneously, but there is no clear indication in their work that they meant this to literally mean 'occurring at the same time' or rather occurring in close and sometimes overlapping proximity to each other across time. I suspect it is the latter, and given the centrality of simultaneity to the definition of organizational ambidexterity, I suspect it would be dangerous to force an assumption that all issues pertaining to the tension between exploration and exploitation happen exactly concurrently across all levels of a firm. More likely is the distribution of simultaneous tensions across the firm.
} 
2010; Stadler et al., 2014). This has tentatively been called 'domain ambidexterity' (Lavie et al., 2010). It is advantageous compared to structural separation because it overcomes the inherent trade-off between exploration and exploitation and circumvents the need for unique structures and forms of coordination; it is advantageous compared to contextual ambidexterity because its organization and resource demands are offset by using the specializations of others elsewhere or outside the firm; and overcomes the inertial challenges posed by temporal transition. Very little research exists on this form of ambidexterity to draw conclusions about its relative value. It does not quell March's (1991) concern that specializing in one activity only can cause systems and routines to reproduce that smother a capability from forming now and in the future for the missing specialism. It also risks making the firm entirely reliant on outside partners or require an expensive round of future acquisitions to provide the missing capability (Hughes and Perrons, 2011).

Having examined the forms organizational ambidexterity may take, it is apparent that resolving the decision about which organizing principle to select relies on both context and level of analysis. An increasing number of studies depart from the exclusive firm-level origins of organizational ambidexterity. On the one hand, this has diluted March's (1991) original focus and has introduced an extra level of complexity to the organizational ambidexterity debate that is not always helpful. But on another, it opens novel opportunities for a multilevel understanding of what is ultimately a theoretically and practically difficult matter: achieving organizational ambidexterity. In some sense, this is rightly so because, as O'Reilly and Tushman (2013) argue, few firms should be able to achieve the pinnacle of ambidexterity, or else it cannot offer a competitive advantage. Thus, the thorny issue of the focus and subject of organizational ambidexterity will now be examined.

\section{THE FOCUS AND SUBJECT OF AMBIDEXTERITY}




\section{Levels of Analysis}

March's (1991) original discussion of exploration and exploitation located the ambidexterity problem at the firm level and as such, organizational ambidexterity is a firm-level construct. In a multi business unit firm, organizational ambidexterity has also been treated at the business unit level, and this can be traced back to Duncan (1976). A further extension of this, albeit one that makes an assumption that a single firm does not need to manage both exploration and exploitation within its boundaries, have been studies at the interfirm level (Im and Rai, 2008; Lavie and Rosenkopf, 2006; Stadler et al., 2014; Stettner and Lavie, 2014). These are not controversial levels of analyses.

In recent times, however, the focus on the firm and its units has been diluted, with organizational ambidexterity extended to include senior managers (Smith and Tushman, 2005) or the senior team (Halevi, Carmeli and Brueller, 2015; Jansen George, Van den Bosch and Volberda, 2008; Lubatkin et al., 2006), managers (Mom, Van den Bosch and Volberda, 2009) and individuals throughout the organization (Birkinshaw and Gibson, 2004; Jasmand, Blazevic and de Ruyter, 2012) and teams within the organization (Huang and Cummins, 2011). These studies function at the individual level or team level. The origins of this can be traced back to the work of Gibson and Birkinshaw (2004). While credited with originating the idea of contextual ambidexterity, their theoretical and empirical treatment contained a distinctly behavioural component. This important distinction led to a shift from considering organizational ambidexterity at the firm or unit levels only. First, it recognized that the effects of organizational ambidexterity may not be constant across different levels of analysis and may accumulate at specific levels (Junni et al., 2013). Second, it recognized that its implementation transcends structure to include the internal environment of the firm and the people within it (Birkinshaw and Gibson, 2004; Gibson and Birkinshaw, 2004). 
Simsek (2009, p.602) appears to be unconvinced of the value of this dilution, arguing that, "there may be individual, team, or functional usages or implications of the concept that are not related to the organization... adopting the organization as the unit of analysis also helps to differentiate OA [organizational ambidexterity] from constructs such as structural ambidexterity (Benner and Tushman, 2003) and contextual ambidexterity (Gibson and Birkinshaw, 2004) that refer to the methods, practices, and processes that an organization uses to attain OA.” Unless we define and theoretically circumscribe organizational ambidexterity sufficiently, we run a risk of confusing what it is and what the theory is meant to predict. Stated differently, there is a danger that the construct and theory of organizational ambidexterity becomes incapable of distinguishing itself from other related concepts in a way that preserves its distinctiveness and contribution as a theory.

There is a counterview to this position by Birkinshaw and Gupta (2013), however. Birkinshaw and Gupta (2013, p.294) argue that, "[t]here is no unit of the organization... that does only one thing. We can resolve the ambidexterity "dilemma" at the organizational level, but we then create a new set of dilemmas at the operational unit level, with the unit managers having to decide for themselves what the relative balance should be between exploration and exploitation. This logic then gets repeated down through the various levels of hierarchy in the organization until we get to individual employees." The authors went so far as to suggest that the most ordinary or mundane production worker or call centre worker has to deal with at least some version of the ambidexterity problem, such as how much time to dedicate to increasing efficiency versus developing new and perhaps more effective ways of working. This may be something of an extreme extrapolation of the matter because the worker in question may have no say over their ability to do their job differently or make any official amendments to it — only unauthorized acts of improvisation or creativity could then be carried out. Yet, the idea that a system of effects is at play and needs managing to achieve 
organizational ambidexterity may provide us with one very profound reason as to why organizational ambidexterity is rare and difficult to achieve to an excellent standard.

Much of the shift in the level of analysis has been to the individual level. Birkinshaw and Gibson (2004) spoke about the qualities of ambidextrous individuals so that employees could decide for themselves how and when to apply alignment and adaptability (or exploitation and exploration, respectively). This does make certain assumptions about the freedoms of individuals across the firm to behave in these ways. To this end, O'Reilly and Tushman (2004, p.81) conclude that "ambidextrous organizations need ambidextrous senior teams and managers." It is precisely because organizational ambidexterity is sensitive to managers' decision-making processes (Rivkin and Siggelkow, 2003) and the extent to which they engage in routine and nonroutine activities (Adler et al. 1999) and manage the conflict between them (Duncan, 1976) that much of the research at the individual level has been focused on the top management team.

Smith and Tushman (2005) specify that it is incumbent on senior leaders and their teams to manage the strategic contradictions that come along with exploration and exploitation activities. In doing so, these senior managers need 'paradoxical cognition' to articulate a paradoxical frame, differentiate between the strategies and architectures underpinning exploration and exploitation, and integrate the two into the firm (Smith and Tushman, 2005). An organization's ability to manage the association between exploration and exploitation then relies on its senior management's capacity to offset the conflict between them (Helfat and Peteraf, 2009). This research has been supplemented by studies examining top management behavioural integration to address the level of the senior team's dedication and unity of effort towards ambidexterity, the quality of information exchange, collaboration and joint decision-making (Lubatkin et al., 2006). This behavioural integration is even more 
important when the firm's task environment is characterized by high dynamism (Halevi et al., 2015).

Senior managers' actions depend on their cognitive and behavioural inclinations, though. As summarized by Lavie et al. (2010), risk-averse senior managers are motivated to execute activities whose outcomes are proximate, certain and immediate (i.e., exploitation), while risk-prone managers are more likely to be motivated by longer-term survival and performance aspirations (i.e., exploration). Senior management maturity may also diminish the appetite for risk, prioritizing exploitation while driving out exploration (e.g., Hambrick and Fukutomi, 1991; Hambrick, Finkelstein and Mooney, 2005; O’Reilly and Tushman, 2008). Managers' ambitions may also play a part (Junni et al., 2015). These matters are important because the orientation of the senior manager and the dynamics of the circumstances surrounding them can reinforce their patterns of learning and experience, fortifying a tendency to behave in ways that allocate resources towards specific activities potentially at a cost to another (and therefore jeopardize organizational ambidexterity). What is unknown, however, is whether the composition of the senior team matters to achieving organizational ambidexterity or whether functional expertise on the board matters.

Middle managers have largely remained absent in this discussion (cf. Hodgkinson, Ravishankar and Aitken-Fischer, 2014) despite their importance to innovation and corporate entrepreneurship, for example (Hornsby, Kuratko and Zahra, 2002). Some works in the leadership field have presented arguments about 'ambidextrous leadership', citing its importance for innovation (Rosing, Frese and Bausch, 2011) and learning (Yukl, 2009). Ambidextrous leadership uses what Rosing et al. (2011) describe as 'opening' and 'closing' behaviours where opening behaviours are a set of leader behaviours that include encouraging doing things differently, experimenting, providing opportunities for independent thought and action and supporting attempts to challenge the status-quo. These are aligned with 
exploration behaviour. Closing behaviours are concentrated on directing employee behaviours by taking corrective action, setting specific guidelines, and monitoring goal achievement. These are aligned with exploitation behaviour. Birkinshaw and Gibson (2004) described ambidextrous individuals as multitaskers and Mom et al. (2009) found that a manager's decision-making authority positively relates to their ambidexterity, their participation in cross-functional interfaces improves their ambidexterity and the connectedness of the manager to other organization members positively relates to their ambidexterity. The danger of this debate, however, is that it assumes all of these behaviours are consistently positive across managers and individuals within a firm regardless of functional level. Studies examining the roles of specific functions are lacking and especially research of those functions whose remit often extends beyond their immediate functional specialty (e.g., marketing).

The purpose of this section of the review was to draw the reader's attention to the rapid fragmentation of the field of organizational ambidexterity witnessed through the dilution and extension of levels of analyses. Allied to this, however, is a far greater problem: the broad treatment ascribed to the subject of ambidexterity. So far this paper has been focused almost exclusively on the classic exploration-exploitation problem, and with good reason. But many recent studies probing matters of ambidexterity have taken very different points of view and this causes a great deal of difficulty in arriving at a clear narrative about what organizational ambidexterity theory can and cannot (or should and should not) address.

\section{Units of Analysis}

One of the consequences of the prolific study of organizational ambidexterity has been the dilution to abstract levels of what the function and use of organizational ambidexterity really is. This has not been helped by provocative statements that generalize organizational 
ambidexterity into very broad terms and by many subsequent studies speaking to matters of ambidexterity but with very different theoretical frames of reference. For example, in simple terms, organizational ambidexterity has been boiled down to "the ability to do two things simultaneously", but as O'Reilly and Tushman (2013, p.330) argue, this is simply not enough as it may lead to the study of phenomena that have "little to do with the practical tensions involved in how managers and organizations deal with exploration and exploitation". To paraphrase O'Reilly and Tushman (2013, pp.330-331), the risk in applying the term so broadly is that it loses meaning, becoming whatever one wants it to be, and applied to phenomena that have little to do with the tensions involved in ensuring firm survival (the "sine qua non of organizational ambidexterity", p..330). Provocative statements abound, such as Birkinshaw and Gupta's (2013) point that the idea of human ambidexterity has been adapted to mean an “organization's capacity to do two different things equally well” (p.287), when in fact this is a disservice to the complexity of the literature and the origins of organizational ambidexterity as has been discussed in this paper to this point.

This problem becomes specifically acute when looking at the subject of organizational ambidexterity research, or the unit of analysis, or the 'what' is of interest among research studies. For example, Nosella et al. (2012) decried the apparent disordered development of research made in the name of organizational ambidexterity, emanating from discrepancies in the types of tensions being considered among studies and its use in many fields, each time adopting a different theoretical literature stream as a reference point (see Raisch and Birkinshaw, 2008). Inconsistency in vocabulary and inconsistent (or shallow) theoretical treatment run the risk of causing confusion among the specific and differential effects of organizational ambidexterity. Consistent with O'Reilly and Tushman's (2013, p.331) concern, "if the term "organizational ambidexterity" continues to be used to describe 
highly disparate phenomena, our insights into how firms actually explore and exploit are likely to become less and less useful."

While well-meaning, this call, in fact, has several aspects to it that may not be readily apparent to scholars. Two types of issues plague the matter of 'what' is of interest. The first aspect is the nature of the tension and the second is the subject of the tension. For example, on the matter of the nature of the tension, the original concept of organizational ambidexterity was used to capture the tensions associated with exploration and exploitation. Yet, studies pointing towards organizational ambidexterity have also spoken about a range of other tensions including induced and autonomous strategic processes (Burgelman, 1991, 2002), static efficiency and dynamic efficiency (Ghemawat and Ricart i Costa, 1993), leverage and stretch (Hamel and Prahalad, 1993), routine and nonroutine (Adler et al., 1999), selective and adaptive strategic actions (Volberda, Baden-Fuller and Van den Bosch, 2001), alignment and adaptability (Gibson and Birkinshaw, 2004), efficiency and flexibility (Ebben and Johnson, 2005) among many others (see Raisch and Birkinshaw, 2008, for a detailed review). Some of these parallel the ideas of exploration and exploitation but the inconsistency in vocabulary and ideas (and theoretical grounding) risks diluting organizational ambidexterity into a meaningless theory or construct that tries to be all things to everything. Birkinshaw and Gupta (2013) and Gulati and Puranam (2009) provide a very straightforward reason for why this has happened. Put simply, organizations are attempting to address many types of tensions and dualities. The problem is that unless organizational ambidexterity is carefully defined and theoretically grounded, virtually any situation in which there are competing opposites might call for ambidexterity. This carries the risk that scholars generate a flawed set of assumptions for their study, our ability to make meaningful comparisons across studies becomes ever more difficult, and what it means to be ambidextrous and to manage tensions that are actually to do with tensions in ensuring firm survival becomes harder to distinguish (March, 1991; 
O'Reilly and Tushman, 2013; Tushman and O'Reilly, 1996). The primary tension fundamental to firm survival is the tension between exploration and exploitation and should remain at the core of any thesis of organizational ambidexterity. Any thesis must also address or be sensitive to the six fundamental elements of organizational ambidexterity discussed in this paper for studies to demonstrate sufficient theoretical grounding: simultaneity versus punctuation, trade-off and balance, synchronicity and dexterity, magnitude, managing tension, and firm survival.

The second aspect is the subject of the exploration-exploitation tension. The twin concepts of exploration and exploitation are a key feature among studies of organizational ambidexterity whether among organization and management studies or marketing-related studies (see Tables 1 and 2). Exploration and exploitation are well-defined and are to do with learning and innovation (Dittrich and Duysters, 2007; Gupta et al., 2006; He and Wong, 2004; Kim and Atuahene-Gima, 2010; Kyriakopoulos and Moorman, 2004; Levinthal and March, 1993; March, 1991, 2006; Stadler et al., 2014; Tushman and O’Reilly, 1996). However, Simsek (2009) opens the door to the locus of exploration and exploitation to be quite wide, describing organizational ambidexterity as an “organization's exploitative and exploratory attainments" (p.599, emphasis added). Studies have indeed examined very different forms of exploration and exploitation than may have been envisaged by March (1991) and Tushman and O'Reilly (1996). This is well-illustrated in Tables 1 and 2 when comparing the columns titled 'unit of analysis' and 'subject of ambidexterity'. For example, in marketing-related studies, the subject of ambidexterity has almost exclusively been exploration and exploitation but the analysis has varied away from innovation and learning to include marketing strategy (Kyriakopoulos and Moorman, 2004) and its implementation (Prange and Schlegelmilch, 2009), competencies and capabilities (Atuahene-Gima, 2005; Yalcinkaya et al., 2007), strategy (Judge and Blocker, 2008) and innovation strategy (Morgan 
and Berthon, 2008). There is somewhat less variation in organization and management studies about the focus of exploration and exploitation but it too is not without its problems (see Nosella et al., 2012; O'Reilly and Tushman, 2013). This is a problem because we risk categorizing as exploration and exploitation phenomena that are very different to each other, research findings for which may be peculiar to the specific context or peculiar to the idiosyncratic nature of the phenomena in question. There is also a high risk that ambidexterity becomes distant from the organization: in essence, a firm ambidextrous in its marketing strategy is not inherently organizationally ambidextrous in its innovation or learning activities and the effects such foci of ambidexterity may have might vary greatly. Together, this only serves to exacerbate the challenges surrounding the practical problem of how organizations and managers can feasibly implement organizational ambidexterity (Nosella et al., 2012; Stettner and Lavie, 2014). To date, there is no study that compares the ambidexterity of different foci of exploration and exploitation.

The purpose of this examination was to reveal to interested readers the benefits and pitfalls of characterizing the unit of analysis of organizational ambidexterity. Focusing on exploration and exploitation (or tying related constructs conceptually and theoretically to them) provides a greater consistency with the theory of organizational ambidexterity but even then, how exploration and exploitation are characterized is important. Greater precision allows a comparable body of findings to develop and enables scholars to contribute meaningful theoretical advancements and enhancements. But claims of contribution to theory cannot come from adding to existing imprecision, by diluting the nature of organizational ambidexterity yet further (i.e., by generalizing it to dualities that are not to do with the tensions in ensuring firm survival), and by extending exploration and exploitation to phenomena removed from organizational ambidexterity (e.g., to matters at the functional or individual level) without re-connecting that back to the original theory. Without this 
theoretical and conceptual precision, the uniqueness of a theory of organizational ambidexterity is lost, construct validity is compromised, and we impede our ability to enhance our knowledge base as results from one study (or a group of studies incomparable to each other) cannot be used to build theory for future studies of organizational ambidexterity. Concept travelling, increasing the extension of a concept while maintaining conceptual precision, is preferable for increasing the generalizability of ambidexterity compared to concept stretching. Concept stretching sees researchers adding additional attributes to a concept while simultaneously attempting to increase the number of cases to which it is applicable to, thereby jeopardizing conceptual precision (e.g., George and Marino, 2011; Osigweh, 1989).

O’Reilly and Tushman (2013) attribute the measurement of organizational ambidexterity as another direct feature of this problem. This will now be examined.

\section{MEASURING AMBIDEXTERITY}

Measuring, or calculating, ambidexterity is a sizeable challenge. The literature to date suggests three ways to determine a firm's degree of ambidexterity (regardless of its subject or form). These are subtractive, additive and multiplicative (Lubatkin et al., 2006). These existing measurements of ambidexterity speak to both the relative quality, or magnitude, of ambidexterity and the relative balance/imbalance within the firm of the two opposing forms of activity that constitute the subject of ambidexterity. The subtractive speaks to Cao et al.'s (2009) 'balance dimension of ambidexterity' while additive and multiplicative speak to their 'combined dimension of ambidexterity'. 5

\footnotetext{
${ }^{5}$ There is an additional element to this debate. If exploration and exploitation are considered to be separate constructs then they should be measured separately (Birkinshaw and Gupta, 2013; Junni et al., 2013; O'Reilly and Tushman, 2013), but, if they are on a continuum (something implied in the idea of balance), a single variable is potentially preferable (Lavie et al., 2010). This matter is unresolved and not helped by evidence from Junni et al. (2013) that separate measures are more strongly related with firm performance. A debate about the
} 
The balance dimension corresponds to the idea of a firm maintaining a close relative balance between exploration and exploitation. For example, He and Wong (2004) calculate imbalance (treated as an antonym of ambidexterity) by examining for absolute differences between exploitation and exploration. This measurement system determines the degree of (im)balance between the two dimensions for which ambidexterity is considered desirable. The combined dimension corresponds to their combined magnitude. For example, Lubatkin et al. (2006) indicate that the magnitude of ambidexterity may be calculated by summing or creating an interaction term for exploitation with exploration. This measurement system determines the quality of ambidexterity by capturing the degree to which the two dimensions for which ambidexterity is considered desirable are sufficiently strong.

Cao et al. (2009) propose that the balance dimension and combined dimension are conceptually distinct. The body of evidence to support this assumption is limited and studies to date do not compute both forms concurrently in determining a unitary measure of ambidexterity. This is problematic when trying to determine the contribution ambidexterity makes to firm performance. First, subtracting exploration and exploitation from each other creates a positive or negative value where any deviation from zero is considered 'bad'. But, studies (e.g., He and Wong, 2004) using this measurement system are potentially flawed because the value that is calculated is inherently dependent on which dimension is inserted into the equation first. For example, as a simple experiment, let's say on a Likert scale between 1 and 7, a common measurement scale for exploration and exploitation, a firm scores 2 on exploration but 7 on exploitation; depending on whether exploration or exploitation is used first in the measurement system, the outcome will either be 5 or -5 ; reversing the equation changes the polarity of the value resulting in a materially different value inputted into any regression equation. Second, any calculation of ambidexterity based of the paper is to specifically tackle the problem of calculating the measure of organizational ambidexterity. 
on balance tells us nothing about the standard of that balance. For example, continuing the experiment moments ago, a firm scoring 7 on exploration and 7 on exploitation is no different from a firm scoring 2 on exploration and 2 on exploitation; both would exhibit balance scores of zero, as intended for 'excellent' balance. Yet, the standard of ambidexterity between the two firms is materially different. The first is excellent at both activities while the second is poor. Yet, under the subtractive measurement system, and the balance dimension alone, this material detail is lost. Third, the multiplicative measurement system is not inherently superior either because its values for ambidexterity are inflated if the degree of imbalance is not accounted for. For example, further continuing the experiment, a firm scoring 7 and 7 on exploration and exploitation respectively has the highest possible score of 49; but multiplication omits the central tenet of the ambidexterity thesis that doing both exploration and exploitation to a good standard is superior to excellence at one activity alone. So, take a firm scoring 4 on both exploration and exploitation respectively versus a second firm scoring 6 and 3 respectively. The first firm would have a score of $16(4 \times 4)$ but loses out to the second firm who would score 18 (6x3). The second firm would prima facie appear to be 'better' according to this measurement system. This runs counter to the ambidexterity thesis. If the relative imbalance was accounted for, the second firm would score 15 (18-3) (although, as mentioned above, this depends on how that imbalance is calculated and the score might inflate to 21 , creating yet more error in the nature of that firm's apparent degree of ambidexterity). This analysis speaks to Simsek's (2009, p.603) posiiton that, "an organization with low levels of exploitation and exploration is 'balanced', but not ambidextrous."

Scholars (and managers) should consider very carefully their choice of measurement system when performing any empirical analysis of organizational ambidexterity, and particularly when examining its effects on firm performance. Extant measurement systems to calculate ambidexterity are all flawed. Ultimately, the selection or combination of 
measurement (or calculative) components must align with the theoretical assumptions of each study. Concurrently, scholars are advised to innovate or consider new, different ways to measure, calculate or determine ambidexterity. This may call for efficiency frontier calculations (e.g., stochastic frontier estimation to determine the quality of one firm's ambidexterity in input-output terms versus its peers) used to good effect in the capabilities literature (e.g., Dutta, Narasimhan and Rajiv, 2005) or consider the configuration of exploration and exploitation (e.g., Hughes et al., 2017).

\section{ORGANIZATIONAL AMBIDEXTERITY AND ITS CONSEQUENCES}

The emergence of organizational ambidexterity as a phenomenon, construct and theory of interest heralded a wave of studies investigating its effects on firm performance. This was necessary to evidence theoretical expectations about the value of organizational ambidexterity both as an object of study and as a goal for high-performing organizations; otherwise it would disappear into obscurity. As Birkinshaw and Gupta (2013, p.291) put it, "[a]s the new kid on the block, ambidexterity research has to show that it offers insights that could not be gained from [another] perspective." Yet, empirical evidence of the effects of organizational ambidexterity is mixed (Junni et al., 2013). The rush to empirically evidence its effects has outpaced vital research needed into its conceptualization, operationalization and measurement.

Whether as a balanced or combined dimension, firms that achieve ambidexterity should be well-placed to overcome a success trap associated with excessive exploitation (where current capabilities, products and services are refined to highly efficient states but vulnerable to new ideas and market changes), and a failure trap associated with excessive exploration (where new ideas are underdeveloped such that they do not generate enough 
income for the firm or that they fail to resonate sufficiently with the market to be accepted). Despite March's (1991) insistence of a trade-off, ultimately, those that can achieve a balance while performing both exploration and exploitation to as high a standard as possible stand to gain the most if the ambidexterity thesis holds true. The general direction of travel among studies of organizational ambidexterity and firm performance is a positive one (Junni et al., 2013; O’Reilly and Tushman, 2013). O’Reilly and Tushman (2013) provide a detailed summary of this literature and Junni et al. (2013) offer a meta-analysis of the relationship between organizational ambidexterity and performance. To avoid repetition, a summary of some of the known positive consequences is presented prior to a discussion on some of the more contentious findings.

Organizational ambidexterity has been positively associated with measures of firm growth and sales growth (e.g., Auh and Menguc, 2005; He and Wong, 2004; Nobeoka and Cusumano, 1998) including longitudinally over time (Geerts, Blindenbach-Driessen and Gemmel, 2010); studies using subjective measures (e.g., Bierly and Daly, 2007; Cao et al., 2009; Gibson and Birkinshaw, 2004; Hughes et al., 2010; Lin, McDonough, Lin and Lin, 2013; Lubatkin et al., 2006; Morgan and Berthon, 2008) and objective measures (Goosen, Bazzazian and Phelps, 2012; Uotila, Maula, Keil and Zahra, 2008; Voss and Voss, 2013; Wang and Li, 2008) of firm performance have reported positive effects; and others find support for March's (1991) claims that ambidexterity contributes to firm survival (e.g., Cottrell and Nault, 2004; Hill and Birkinshaw, 2014; Mitchell and Singh, 1993; Piao, 2010).

However, other scholars have found more complex effects. Caspin-Wagner, Ellis and Tishler (2012) and Uotila et al. (2008) evidence an inverted U-shaped relationship between ambidexterity and financial performance. Uotila et al. (2008), pointing to the challenges in maintaining the exploration-exploitation balance in their study, reported that $80 \%$ of the firms in their sample overemphasized exploitation at a cost to exploration. This corresponds with 
March's (1991) argument that exploitation over time self-replicates its routines and procedures more rapidly than exploration leading to an inevitable tension and trade-off. This also speaks to Tushman and O'Reilly's (1996) argument that actually achieving ambidexterity is rare and hard to sustain. Menguc and Auh (2008) predicted a negative effect from ambidexterity on firm performance based on whether prospector firms add exploitation to exploration and defender firms add exploration to exploitation. While their direct relationships garnered no statistical significance, they did find that the ambidexterityperformance relationship depends on market orientation, creating significant positive effects for prospectors but negative effects for defenders. Moreover, Atuahene-Gima (2005) found that exploration and exploitation have opposite effects on radical and incremental innovation performance, respectively, but that an attempt at ambidexterity offers no benefit to incremental innovation performance and harms radical innovation performance. Other studies suggest that organizational ambidexterity can have further negative effects on firm performance by being duplicative and inefficient (Ebben and Johnson. 2005; Van Looy, Martens and Debackere, 2005). The results of these studies speak to the concern of Gupta et al. (2006) that specialization may be superior to ambidexterity.

These findings point to the contingent nature of the ambidexterity-performance relationship. Several studies report that the performance implications of ambidexterity are contingent on external environment conditions (such as dynamism and munificence) (e.g., Cao et al., 2009; Caspin-Wagner et al., 2012; Goosen et al., 2012; Jansen, Van den Bosch and Volberda, 2005; Jansen, Vera and Crossan, 2009; Sidhu, Volberda and Commandeur, 2004; Siggelkow and Rivkin, 2005; Uotila et al., 2008; Wang and Li, 2008), including competitive intensity (Auh and Menguc, 2005); resource availability (Cao et al., 2009; Goosen et al., 2012; Voss and Voss, 2013) and resource slack (Voss et al., 2008); internal firm conditions resulting from age and size (Chang and Hughes, 2012; Chang et al., 2011; Lubatkin et al., 
2006; Voss and Voss, 2013; Voss et al., 2008); and industry, with Junni et al. (2013) reporting that organizational ambidexterity is more important for firm performance in nonmanufacturing rather than manufacturing firms in their meta-analysis and Geerts et al. (2010) reporting differences between manufacturing and service firms too.

These contingencies are important for several reasons. First, Voss et al. (2008) showed that for SMEs, when little resource slack is available, firms focus on exploitation but when new resources are introduced, they divert attention to exploration. Chang and Hughes and Chang et al. (2011) argue that SMEs face considerable challenges in setting in place ambidexterity because structural separation is either unfeasible or impossible. This indicates a reliance on contextual ambidexterity in comparison to much of the work on structural ambidexterity and raises questions as to whether the resource demands of ambidexterity can (or should) be met internally.

Second, Voss and Voss (2013, p.1459) highlight how age and size generate two ambidexterity paradoxes, in which, “(1) larger, older firms have the resources, capabilities, and experience required to benefit from a product ambidexterity strategy, but larger, older firms are less likely to implement product ambidexterity; and (2) only larger firms have the resources and capabilities required to benefit from a market ambidexterity strategy, but developing and sustaining market ambidexterity is necessary to drive long-term growth." This debate raises a further problem to do with whether a firm seeks to achieve a balance dimension of ambidexterity, a combined dimension of ambidexterity or both (Cao et al., 2009). Cao et al. (2009) found that a balance dimension is more beneficial to resourceconstrained firms but a combined dimension is more beneficial to firms having greater access to internal and/or external resources. An unanswered question is whether opting for a balance dimension because of resource constraints disadvantages a firm compared to a rival capable of pursuing a combined dimension. The possibility of this is set by Simsek (2009) who argues 
that a firm can be balanced in terms of their exploration and exploitation but not necessarily ambidextrous if the standard of the two activities is insufficient.

Third, inconsistencies in measuring the form of ambidexterity within firms and the meaning of exploration and exploitation across industries may account for conflicting findings (e.g., Junni et al., 2013; O'Reilly and Tushman, 2013). There is a danger that what it means to explore or exploit or be ambidextrous varies from one firm, set of firms, or industry to another, such that effects that are found (or indeed not found) reflect a set of idiosyncratic circumstances at play in a particular sample or study context. Junni et al. (2013) also find that the effects of organizational ambidexterity appear stronger when combined measures (capturing both exploration and exploitation, instead of a continuous measure) of organizational ambidexterity are used, when perceptual measures of performance are used and when a cross-sectional or multimethod research design is used vis-à-vis longitudinal designs.

Fourth, Durisin and Todorova (2012) find that organizing for and benefiting from organizational ambidexterity can be more complex than is often detected through quantitative methodologies. While not specifically examining performance, Durisin and Todorova's study is important to this debate for two reasons: (1) they found that the organizational structure and culture for incremental innovation (a form of exploitation) did not differ from the structure and culture for discontinuous innovation (a form of exploration) alongside the dimensions expected from theory; (2) the discontinuous innovation business unit had to be reintegrated into the firm to ensure sustained growth and during that reintegration process, organizational capabilities mutated. Some caution is needed in interpreting these results, for example, whether the case company for their work, based in a technology-based industrial setting, was unusual and was not experiencing exploration-exploitation as a trade-off (Cao et al., 2009; cf. Tushman and O'Reilly, 1996). Nevertheless, for scholars, this raises questions 
about research design and about theorizing and empirically analysing the wider system of effects, boundary conditions and contingencies to do with organizational ambidexterity.

Despite the considerable amount of research made into the consequences of organizational ambidexterity, there are considerable opportunities for scholars to develop better studies with better measurement of organizational ambidexterity that accounts more carefully for its sensitivity to context and contingency factors. With this in mind, the paper now moves to develop the burning research questions that can advance our understanding of organizational ambidexterity and performance in the field of marketing.

\section{BURNING RESEARCH QUESTIONS FOR THE STUDY OF AMBIDEXTERITY}

\section{AND MARKETING}

\section{Marketing's Contribution to Organizational Ambidexterity?}

Scholars have only just started to scratch the surface of the relationship between marketing and organizational ambidexterity. Marketing is a rich field with important effects on organizational learning, innovation and firm performance, and there are aspects of marketing that lend themselves directly to the study of organizational ambidexterity, such as market orientation (which has been the main subject of existing studies of marketing and organizational ambidexterity), co-creation, service-dominant logic, marketing resources, and the marketing-finance interface, for example.

It is vital to ascertain whether investing in marketing activity creates a set of conditions that resolve the inherent tension in the ambidexterity thesis or exacerbates that tension. For this to be answered, marketing scholars must provide a careful treatise of marketing's effects within the rubric of ambidexterity theory. This ensures that predicted effects are theoretically robust so that any empirically-observed relationships actually do advance theory. The danger is that without robust theoretical grounding, empirical 
relationships become little more than statistical artefacts or resemble effects that are specific solely to the measurement or context of a particular study. O'Reilly and Tushman (2013) warn that studies of ambidexterity measuring exploration and exploitation with Likert scales tend to use common measures but differ substantially in their samples and contexts. While their psychometric properties might be robust, their context sensitivity and applicability is yet to be established. For example, in marketing, Kyriakopoulos and Moorman (2004) study Dutch firms in the packaged food industry, Bierly and Daly (2007) study small manufacturing firms, Morgan and Berthon (2008) study bioscience firms, Voss and Voss (2013) study theatres, Hughes et al. (2010) study international new ventures and Vorhies et al. (2011) study a selection of firms from across several goods and services industries. Scholars risk categorizing as exploration and exploitation potentially very different phenomena if samples are too niche or dispersed (O'Reilly and Tushman, 2013). This discussion yields two important research questions for marketing scholars:

RQ1: How, and under what conditions, might firms that prioritize marketing exhibit more or less organizational ambidexterity?

RQ2: How might an investment in marketing activity benefit organizational ambidexterity across homogeneous and heterogeneous samples of firms? To what extent are the benefits of marketing for organizational ambidexterity industry-specific?

The possibility that exploration and exploitation in one study are not the same as another creates problems in developing a cohesive, consistent and thorough body of knowledge. This is magnified by the approach taken to model organizational ambidexterity. For example, a contingency model predicts that the antecedents and effects of organizational 
ambidexterity are contingent on internal and external factors. The majority of extant works reflect contingency models, but a configuration model is a viable alternative. A configuration model of ambidexterity would suggest that a dexterous balance of high-quality exploration and exploitation depends on how a series of factors within or outside the firm (or unit or function) come together to create the context for ambidexterity. Hughes, Hughes and Morgan (2007) evidence that the configuration of exploration activity is important, with its effects on firm performance diminished when exploitation activity is excessive. Allied to this matter is the extent to which organizational ambidexterity is consistent across an entire organization and consistent over time, is function or domain specific, or has differential effects. Novel methodologies including configuration analysis, cluster analysis, multi-level modelling, qualitative comparative analysis, and longitudinal analysis would be advantageous in studying this problem. Indeed, in their meta-analysis, Junni et al. (2013) show that the reported performance effects of organizational ambidexterity are sensitive to research design, suggesting that scholars must consider the ambidexterity problem from a variety of methodological avenues for a complete picture of its system of effects to emerge. Thus:

RQ3: What are the internal and external contingencies that act on the marketingambidexterity-performance relationship?

RQ4: How might marketing contribute to a configurational treatment of organizational ambidexterity?

Marketing and the Relationship between Organizational Ambidexterity and Performance 
From a marketing point of view, there are several interesting questions that the ambidexterity literature has entirely ignored because of its obsession with the ambidexterity-performance relationship at the firm or organizational level. First, Gibson and Birkinshaw (2004, p.214) stated that, "a useful analogy to contextual ambidexterity is the market orientation construct in the field of marketing", arguing that, "the process of developing market orientation in a firm is recognized to be complex, time-consuming, and causally ambiguous. Research has identified some of the necessary systems and techniques needed (such as high-quality market intelligence), but these techniques do not have a direct effect on performance; rather, they contribute to the overall market orientation of a firm, which then leads to performance." Market orientation is not a substitute for contextual ambidexterity. Rather, it is used as an analogy to explain the difficulties in implementing contextual ambidexterity. From a performance point of view, however, it is symptomatic of the emphasis being given to the 'firm' overall, neglecting the vested interests functions and their managers have in achieving their own specific organizational targets. Marketing has particular cause for concern in this regard because, despite evidence of its effects on firm performance, the power and influence of the marketing department has declined (Homburg et al., 2015; Verhoef and Leeflang, 2009). Studies need to consider more carefully its system of effects among a wider selection of performance measures that cross several organizational activities and levels of analysis. Three important research questions originate from this debate:

RQ5: How might organizational ambidexterity advance (or contribute to) marketing's cause and enhance its salience among top managers?

RQ6: What are the key measures of marketing productivity that ambidexterity should be assessed against (e.g., customer-focused ones versus market focused ones)? 
RQ7: How and to what extent does marketing's contribution to organizational ambidexterity affect measures of firm performance?

Second, and related to this discussion, an answer may be found in studies of market orientation and organizational ambidexterity. Positive and negative inconsistencies seen in the performance effects of organizational ambidexterity may stem from moderation effects caused by marketing-related activities. For example, Kyriakopoulos and Moorman (2004) argue that a firm's market orientation provides a unifying frame of reference that allows a firm to combine marketing exploitation and exploration strategies effectively to achieve greater levels of firm performance. Market orientation creates a focus on customer goals, facilitating market information flows between exploitation and exploration strategies and helps integrate the two activities. In turn, Kyriakopoulos and Moorman (2004) found that market orientation facilitates a complementarity of high levels of marketing exploration and marketing exploitation strategies that result in improved new product financial performance. They also found that firms with a weak market orientation engaging in high levels of both strategies display a significant reduction in new product financial performance. AtuaheneGima (2005) also found evidence that market orientation guides managerial decisions toward simultaneously allocating resources to exploit existing product innovation competencies and to developing new innovation capabilities. Menguc and Auh (2008) further this positive view, finding that market orientation can function as a metaculture by integrating the subunit cultures generated by exploration and exploitation. Their empirical evidence indicates that market orientation is needed to mitigate the negative effects of ambidexterity on firm performance. However, the contribution of market orientation has also been questioned. Morgan and Berthon (2008) find mutually exclusive paths in which market orientation only 
leads to exploitative innovation strategy, while generative learning is needed to achieve explorative innovation strategy. Alternate forms of market orientation also cause effects to differ. For example, $\mathrm{Li}$, Lin and Chu (2008) find that proactive and responsive market orientations provide alternate pathways to exploration and exploitation (in terms of radical and incremental innovations, respectively). Collectively, though, these studies do not ascertain how the competing tensions at play (not just between exploration-exploitation but between generative-adaptive, reactive-proactive as well) should be organized, orchestrated and coordinated. An important research question, therefore, is:

RQ8: How should marketing activity be organized and coordinated to facilitate organizational ambidexterity and firm performance?

Despite the richness of the field of marketing, studies of marketing and organizational ambidexterity are few and far between. Beyond market orientation, only a narrow set of subjects have so far been considered. Absent are such matters as co-creation and servicedominant logic, social media and online communities, marketing resources and visioning, and the marketing-finance interface. Research question 8 can be customized to include specific aspects of marketing. Co-creation and service-dominant logic both speak to the idea of involving customers in innovation activities with a view to innovating in ways that transcend the myopic view of the market often held by managers (Roberts, Hughes and Kertbo, 2014). Allied to this is the failure of managers to truly understand their customers (Hult et al., 2017). Social media (Roberts, Piller and Luttgens, 2016), social network sites (Roberts and Candi, 2014) and online communities (Roberts et al., 2014; Füller, 2006; Füller, Jawecki and Mühlbacher, 2007) are also important marketing tools that can be used to develop new products and to launch and promote new products (Roberts, Candi and Hughes, 2017). These 
serve as means to co-opt additional marketing resources for the firm. Yet, our cumulative knowledge of their functioning and effectiveness is still limited, particularly in terms of how they interact with internal organizational resources, activities and priorities. Therein, studies of marketing resources (Kyriakopoulos et al., 2016) and market visioning (Reid and de Brentani, 2010) also find that the composition of the firm's (or the unit's) marketing resources and its (in)ability to vision new markets can affect (positively and negatively) activities we would associate with exploration (e.g., radical innovation, market visioning competence). The usefulness and contributions of these marketing activities and resources for organizational ambidexterity is currently unknown but they are potentially very powerful.

The marketing-finance interface considers the role of the marketing department, its power and its representation (or otherwise) on the Board of Directors (Homburg et al., 2015) and marketing investment (Dutta, Narasimhan and Rajiv, 1999; Luo and Donthu, 2006; Verhoef and Leeflang, 2009) to examine the contribution of marketing to firm performance. The value of marketing investments to strategically-important organizational activities may depend on investments in other parts of the organization. This is likely to have specific implications for ambidexterity since our knowledge of what organizational activities and functions benefit exploration, exploitation or both is very limited. Given that exploration, exploitation and any effort to achieve ambidexterity in one part of the firm is likely to create demands or effects elsewhere in the organization, studying the effects of marketing alone risks providing only a narrow or single contribution to the larger puzzle that is organizational ambidexterity. Moreover, the danger of focusing solely on the circumstances that may govern any beneficial effect from marketing on organizational ambidexterity is that it risks assuming that organizational ambidexterity is a single and consistent construct across an organization. The domain view of ambidexterity challenges this. Accordingly, a further research question follows: 
RQ9: To what extent is the contribution of marketing activities to organizational ambidexterity marketing specific? Is marketing's contribution to the system of effects (a) isolated to one part of the organization, (b) pervasive and organization-wide, or (c) contained to pockets across the firm (in which marketing insufficient on its own for organization-wide ambidexterity)? How might the contribution of marketing to organizational ambidexterity be widened?

\section{Forms of Organizational Ambidexterity}

One of the failings of the organizational ambidexterity literature, and reflected in the uncertainty over which form of organizational ambidexterity is best and how a firm can organize for it (a question that is almost certainly context dependent), is its failure to consider the role of functions or cross-functional activity. First, the separation or partitioning of exploration and exploitation into two separate units to be managed through coordination mechanisms (structural ambidexterity) omits questions about whether specific organizational functions contribute equally or differently to either exploration or exploitation. Second, instead of separation or partitioning, an organization may opt for the collective orientation of individuals towards exploration and exploitation by modifying the internal firm environment and context for their behaviour (contextual or behavioural ambidexterity). However, works by Gibson and Birkinshaw (2004) and Kang and Snell (2009) on contextual ambidexterity make an untested assumption that this approach helps to avoid potential coordination problems and costs carried by structural ambidexterity/partitioning. This is a risky assumption. For example, the idea that "every individual in the organization" can allocate time and effort to behaviours to do with exploration and exploitation (Gibson and Birkinshaw, 2004, p.73) implies that organization-wide exploration is inherently sensible and 
necessary. Can, or should, everyone across all different departments and functions in a firm really carry out ambidextrous actions and not have any kind of coordination problem or cost? Third, Birkinshaw and Gupta (2013) argued that changing the conditions for ambidexterity in one part of the organization is likely to have ramifications elsewhere in the business. To date, this remains almost entirely untested. Lavie et al. (2010) and Stettner and Lavie (2014) also postulate that the organization may be explorative in one part of the business but exploitative in another. This domain ambidexterity can also be supplemented by activities with partners outside the firm's boundaries.

Marketing as a function has changed (Whitler and Morgan, 2017) and its boundaries with other functions are increasingly blurred (Joshi and Giménez, 2014). Organizational configurations have moved increasingly towards the diffusion of Agile principles with Guilds, Chapters and Squads and project-based structures clouding how clearly marketing investments are aligned with traditional marketing activities. Marketing may then operate cross-functionally across the firm to support organizational ambidexterity or serve as a coordination capability when exploration and exploitation are structurally partitioned. From a domain perspective, marketing's unique relationships with social media, online communities and customers may form a completely new method of achieving ambidexterity through external relationships that have yet to receive thought among management scholars.

This discussion raises a series of important research questions:

RQ10: How might marketing serve as a coordination capability or interface between physically separated (or partitioned) units of exploration and exploitation? 
RQ11: What are the unique attributes of a marketing function in comparison to (for example) $R \& D$, operations, finance or human resourcing and do these attributes facilitate organizational ambidexterity or only ambidexterity at the functional level?

RQ12: What are the unique attributes of marketing as a cross-functional activity, and how do these contribute to explorative, exploitative, or ambidextrous initiatives?

RQ13: How can marketing capitalize on users and online communities to co-opt these resources into achieving organizational ambidexterity?

\section{Marketing Resources and Organizational Ambidexterity}

Resourcing organizational ambidexterity is a non-trivial problem. Both exploration and exploitation compete for scarce resources creating some degree of trade-off that is exacerbated by the fact that both require very different processes and activities to take hold in the firm. Even if we adopt the alternative view that both can be reconciled by manipulating context, exploration and exploitation still require considerable resource investment. This has led to questions about whether specialization may yet be superior for some firms (Gupta et al., 2006) or that the domain of ambidexterity needs to be widened to consider network, relational or alliance means to achieve ambidexterity, for example (Lavie et al., 2010).

The resource intensity of organizational ambidexterity is further important when examining SMEs instead of large firms (Chang and Hughes, 2012; Lubatkin et al., 2006; Voss and Voss, 2013). The availability of slack resources diverts attention and work away from exploitation and towards exploration in SMEs (Voss et al., 2008), and attempting to balance ambidexterity is better for these resource-constrained firms than trying to combine both exploration and exploitation to a high standard (Cao et al., 2009). The latter is more 
productive to those firms having greater access to internal and/or external resources. This implies there is at least some threshold point beyond which resource constraints are sufficiently alleviated such that seeking a more ambitious form of ambidexterity (a combined form) is plausible and desirable.

This discussion raises a series of interesting questions for marketing. First, the resource absorption consequences of exploration and exploitation have been routinely ignored. This is apparent in works that call for exploration and exploitation to be balanced but high in magnitude (see Simsek, 2009). Exploration and exploitation may not draw on the exact same resources as each other, and when doing so, may not drain those resources by the same amount. Exploration and exploitation likely call on some similar organizational resources such as financial, time, or human resources (depending on how it is organized) (Hodgkinson et al., 2014), but other resources (such as function-specific ones) may not be the same. For example, Kyriakopoulos et al. (2016) found that greater amounts of market knowledge resources negatively influence a business unit's degree of radical innovation activity and its subsequent commercialization; greater brand resources also diminished radical innovation activity but positively moderated its subsequent effects on performance; and relational resources were beneficial at all times. This suggests that market knowledge resources favour exploitation over exploration, further suggesting that resources themselves have unequal roles to play in achieving organizational ambidexterity. Nevertheless, O'Reilly and Tushman (2013, p.2) warn that exploration alone is inefficient and carries an "unavoidable increase" in bad ideas. Marketing practice may be able to reduce or offset this increase by tying exploration to market knowledge, but only if it drives timely and appropriate market intelligence into the ideation that is part of exploration (cf. Kyriakopoulos et al., 2016). These views can be supplemented by lessons from the service-dominant logic literature (Vargo and Lusch, 2004, 2006) about the co-production of knowledge between the 
firm and the consumer (Blazevic and Lievens, 2008), or involving consumers as lead users (Bogers, Afuah and Bastian, 2010) or co-creators (Roberts et al., 2014) directly in the new product development process. But, that is not to say that all instances or forms of customer co-creation are beneficial as polarized views can arise, customers lack technical knowledge and role ambiguity can undermine innovation processes (e.g., Heidenreich et al., 2015). The following three research questions emerge from this discussion:

RQ14: Do exploitation and exploration always draw on the same resources? Are some organizational resources (e.g., specific marketing resources) more amenable to exploitation or exploration, or favour both and so organizational ambidexterity?

RQ15: What are the contributions of marketing resources to a firm's relative (im)balance between exploration and exploitation?

RQ16: How might relationships with customers as lead users or co-creators facilitate an organizational ambidexterity between exploration and exploitation?

Utilizing the consumer as a co-creator of knowledge or innovation takes advantage of the consumer as an 'operant', higher-order resource (i.e., a resource that acts on other resources) (Madhavaram and Hunt, 2008). Their skills, knowledge and creativity are co-opted into the firm's innovation process as a way of extending and better using the firm's stock of internal resources (Madhavaram and Hunt, 2008; Vargo and Lusch, 2004; Xie, Bagozzi and Troye, 2008). In doing so, the utility of a new innovation can be crystallised at a much earlier stage such that higher-order resources may lessen the risks associated with exploration and so facilitate ambidexterity. 
An alternative intriguing possibility, however, is that organizational ambidexterity itself is a higher-order resource. Exploring organizational ambidexterity as a higher-order resource can be important for the context of marketing and leads to considerations of how organizational ambidexterity might contribute to marketing. Nosella et al. (2012) characterized organizational ambidexterity as a capability to manage tensions born from conflicting activities in the firm, and to realize high levels of both competing activities. This view positons ambidexterity as a composite operant resource acting on the firm's other resources (e.g., those underpinning exploration and exploitation). O’Reilly and Tushman (2008, 2013), however, suggest that ambidexterity may be a collection of capabilities to do with competing in new markets and technologies and adapting in the face of changed market conditions. This is more aligned with an interconnected operant resource. To this end, organizational ambidexterity has the potential to interact with or rely on other operant resources such as network and alliance competences, customer response and market flexibility capabilities, market and entrepreneurial orientations, and marketing planning and market relating capability (see Madhavaram and Hunt, 2008, for a list of various operant resources for marketing strategy). This discussion raises the following research question:

RQ17: How will a conceptualization of organizational ambidexterity as a higher-order resource or capability benefit marketing? How might organizational ambidexterity contribute to or extend the functioning of complex operant resources for marketing strategy?

\section{CONCLUSIONS}

Organizational ambidexterity is one of the most important constructs and theories of our time in organization and management research, yet its future hinges on scholars coming to terms 
with its definitional, theoretical and conceptual, measurement and empirical testing challenges to craft meaningful research studies that advance theory and practice. This paper provides scholars with an in-depth compendium and documentation to treat these issues and serves as a comprehensive guide to safely navigating the minefield that is the study of organizational ambidexterity. Its future also hinges on engaging scholars outside of organization and management studies to fully understand its system of antecedents, effects and dependencies. This paper generates and provides scholars with 17 powerful research questions by which to make major advances in theory and practice to do with organizational ambidexterity. Scholars are strongly encouraged to grasp these opportunities to craft the next stage in the evolution of organizational ambidexterity theory and practice. 


\section{REFERENCES}

Adler, P. S., Goldoftas, B., \& Levine, D. I. (1999). Flexibility versus efficiency: A case study of model change-overs in the Toyota production system. Organization Science, 10, 43-68.

Alvarez, S. A., Barney, J. B., \& Anderson, P. (2012). Forming and exploiting opportunities: The implications of discovery and creation processes for entrepreneurial and organizational research. Organization Science, 24(1), 301-317.

Andriopoulos, C., \& Lewis, M. W. (2009). Exploitation-exploration tensions and organizational ambidexterity: Managing paradoxes of innovation. Organization Science, 20(4), 696-717.

Atuahene-Gima, K. (2005). Resolving the capability-rigidity paradox in new product innovation. Journal of Marketing, 69(4), 61-83.

Auh, S., \& Menguc, B. (2005). Balancing exploration and exploitation: The moderating role of competitive intensity. Journal of Business Research, 58, 1652-1661.

Benner, M. J., \& Tushman, M. L. (2003). Exploitation, exploration, and process management: The productivity dilemma revisited. Academy of Management Review, 28, 238-256.

Benson, J. K. (1977). Organizations: A dialectical view. Administrative Science Quarterly, $22,2-21$.

Bierly, P. E., \& Daly, P. S. (2007). Alternative knowledge strategies, competitive environment, an organizational performance in small manufacturing firms. Entrepreneurship Theory and Practice, 31, 493-516.

Birkinshaw, J., \& Gibson, C. (2004). Building ambidexterity into an organization. MIT Sloan Management Review, 45(4), 47-55.

Birkinshaw, J., \& Gupta, K. (2013). Clarifying the distinctive contribution of ambidexterity to the field of organization studies. Academy of Management Perspectives, 27(4), 287298.

Blazevic, V., \& Lievens, A. (2008). Managing innovation through customer coproduced knowledge in electronic services: An exploratory study. Journal of the Academy of Marketing Science, 36, 138-151.

Bogers, M., Afuah, A., \& Bastian, B. (2010). Users as innovators: A review, critique, and future research directions. Journal of Management, 36, 857-875.

Burgelman, R. A. (1991). Intraorganizational ecology of strategy making and organizational adaptation: Theory and field research. Organization Science, 2, 239-262.

Burgelman, R. A. 2002. Strategy as vector and the inertia of coevolutionary lock-in. Administrative Science Quarterly, 47, 325-357.

Burns, T., \& Stalker, G. M. (1961). The management of innovation. London: Tavistock.

Cao, Q., Gedajlovic, E., \& Zhang, H. (2009). Unpacking organizational ambidexterity: Dimensions, contingencies, and synergistic effects. Organization Science, 20(4), 781-796.

Caspin-Wagner, K., Ellis, S., \& Tishler, A. (2012). Balancing exploration and exploitation for firm's superior performance: The role of the environment. Paper presented at the annual meetings of the Academy of Management, Boston.

Cegarra-Navarro, J. G., \& Dewhurst, F. (2007). Linking organizational learning and customer capital through an ambidexterity context: An empirical investigation in SMEs. International Journal of Human Resource Management, 18, 1720-1735.

Chang, Y.-Y., \& Hughes, M. (2012). Drivers of innovation ambidexterity in small- to medium-sized firms. European Management Journal, 30(1), 1-17.

Chang, Y.-Y., Hughes, M., \& Hotho, S. (2011). Internal and external antecedents of SMEs' innovation ambidexterity outcomes. Management Decision, 49(10), 1658-1676. 
Cottrell, T., \& Nault, B. R. (2004). Product variety and firm survival in the microcomputer software industry. Strategic Management Journal, 25, 1005-1025.

de Rond, M., \& Bouchikhi, H. (2004). On the dialectics of strategic alliances. Organization Science, 15(1), 56-69.

Dittrich, K. and Duysters, G.M. (2007). Networking as a means to strategy change: The case of open innovation in mobile telephony. Journal of Product Innovation Management, 24(6), 510-521.

Duncan, R. B. (1976). The ambidextrous organization: Designing dual structures for innovation. In R. H. Kilmann, L. R. Pondy, \& D. Slevin (Eds), The management of organization (pp. 167-188). New York: North-Holland.

Durisin, B., \& Todorova, G. (2012). A study of the performativity of the "ambidextrous organizations" theory: Neither lost in nor lost before translation. Journal of Product Innovation Management, 29(S1), 53-75.

Dutta, S., Narasimhan, O., \& Rajiv, S. (1999). Success in high-technology markets: Is marketing capability critical? Marketing Science, 18(4), 547-568.

Dutta, S., Narasimhan, O., \& Rajiv, S. (2005). Conceptualizing and measuring capabilities: Methodology and empirical application. Strategic Management Journal, 26, 277-285.

Ebben, J. J., \& Johnson, A. C. (2005). Efficiency, flexibility, or both? Evidence linking strategy to performance in small firms. Strategic Management Journal, 26, 1249-1259.

Eisenhardt, K.M., \& Brown, S.L. (1997). The art of continuous change: Linking complexity theory and time-paced evolution in relentlessly shifting organizations. Administrative Science Quarterly, 42(1), 1-34.

Füller, J. (2006). Why consumers engage in virtual new product developments initiated by producers. Advances in Consumer Research, 33, 639-646.

Füller, J., Jawecki, G., \& Mühlbacher, H. (2007). Innovation creation by online basketball communities. Journal of Business Research, 60(1), 60-71.

Geerts, A., Blindenbach-Driessen, F., \& Gemmel, P. (2010). Achieving a balance between exploration and exploitation in service firms: A longitudinal study. Paper presented at the annual meetings of the Academy of Management, Montreal.

George, B. A., \& Marino, L. (2011). The epistemology of entrepreneurial orientation: Conceptual formation, modeling, and operationalization. Entrepreneurship Theory and Practice, 35(5), 989-1024.

Gersick, C. J. G. (1991). Revolutionary change theories: A multilevel exploration of the punctuated equilibrium paradigm. Academy of Management Review, 16(1), 10-36.

Ghemawat, P., \& Ricart i Costa, J. (1993). The organizational tension between static and dynamic efficiency. Strategic Management Journal, 14, 59-73.

Gibson, C. B., \& Birkinshaw, J. (2004). The antecedents, consequences, and mediating role of organizational ambidexterity. Academy of Management Journal, 47, 209-226.

Gilbert, C. (2005). Unbundling the structure of inertia: Resource versus routine rigidity. Academy of Management Journal, 48, 741-763.

Gilbert, C. (2006). Change in the presence of residual fit: Can competing frames coexist? Organization Science, 17(1), 150-167.

Goosen, M. C., Bazzazian, N., \& Phelps, C. (2012). Consistently capricious: The performance effects of simultaneous and sequential ambidexterity. Paper presented at the annual meetings of the Academy of Management, Boston.

Greiner, L.E. (1972). Evolution and revolution as organizations grow. Harvard Business Review, 50(4), 37-46.

Greiner, L. E. (1998). Evolution and revolution as organizations grow. Harvard Business Review, 76(3), 55-63. 
Gulati, R., \& Puranam, P. (2009). Renewal through reorganization: The value of inconsistencies between formal and informal organization. Organization Science, 20(2), $422-440$.

Gupta, A. K., Smith, K. G., \& Shalley, C. E. (2006). The interplay between exploration and exploitation. Academy of Management Journal, 49, 693-706.

Halevi, M. Y., Carmeli, A., \& Brueller, N. N. (2015). Ambidexterity in SBUs: TMT Behavioral integration and environmental dynamism. Human Resource Management, 54(S1), S223-S238.

Hambrick, D. C., \& Fukutomi, G. D. S. (1991). The seasons of a CEO's tenure. Academy of Management Review, 16(4), 719-742.

Hambrick, D. C., Finkelstein, S., \& Mooney, A. C. (2005). Executive job demands: New insights for explaining strategic decisions and leader behaviors. Academy of Management Review, 30(3), 472-491.

Hamel, G., \& Prahalad, C. K. (1993). Strategy as stretch and leverage. Harvard Business Review, 71(2), 75-84.

Hannan, M. T., \& Freeman, J. (1984). Structural inertia and organizational change. American Sociological Review, 49(2), 149-164.

He, Z., \& Wong, P-K. (2004). Exploration and exploitation: An empirical test of the ambidextrous hypothesis. Organization Science, 15, 481-496.

Heidenreich, S., Wittkowski. K., Handrich, M., \& Falk, T. (2015). The dark side of customer co-creation: Exploring the consequences of failed co-created services. Journal of the Academy of Marketing Science, 43, 279-296.

Helfat, C., \& Peteraf, M. (2009). Understanding dynamic capabilities: Progress along a developmental path. Strategic Organization, 7(1), 91-102.

Hill, S. A., \& Birkinshaw, J. (2014). Ambidexterity and survival in corporate venture units. Journal of Management, 40(7), 1899-1931.

Hodgkinson, I. R., Ravishankar, M. N., \& Aitken-Fischer, M. (2014). A resource-advantage perspective on the orchestration of ambidexterity. The Service Industries Journal, 34(15), $1234-1252$.

Homburg, C., Vomberg, A., Enke, M., \& Grimm, P. H. (2015). The loss of the marketing department's influence: Is it really happening? And why worry? Journal of the Academy of Marketing Science, 43(1), 1-13.

Hornsby, J. S., Kuratko, D. F., \& Zahra, S. A. (2002). Middle managers' perception of the internal environment for corporate entrepreneurship: Assessing a measurement scale. Journal of Business Venturing, 17(3), 253-273.

Huang, S., \& Cummins, J. N. (2011). When critical knowledge is most critical: Centralization in knowledge-intensive teams. Small Group Research, 42(6), 669-699.

Hughes, M., \& Perrons, R. K. (2011). Shaping and re-shaping social capital in buyer-supplier relationships. Journal of Business Research, 64(2), 164-171.

Hughes, M., Filser, M., Harms, R., Kraus, S., Chang, M.-L., \& Cheng, C.-F. (2017). Family firm configurations for high performance: The role of entrepreneurship and ambidexterity. British Journal of Management, forthcoming, DOI: 10.1111/1467-8551.12263.

Hughes, M., Hughes, P., \& Morgan, R. E. (2007). Exploitative learning and entrepreneurial orientation alignment in emerging young firms: Implications for market and response performance. British Journal of Management, 18(4), 359-375.

Hughes, M., Martin S. L., Morgan, R. E., \& Robson, M. J. (2010). Realizing product-market advantage in high-technology international new ventures: The mediating role of ambidextrous innovation. Journal of International Marketing, 18(4), 1-21. 
Hult, G. T. M., Morgeson III, F. V., Morgan, N. A., Mithas, S., \& Fornel, C. (2017). Do managers know what their customers think and why? Journal of the Academy of Marketing Science, 45(1), 37-54.

Im, G., \& Rai, A. (2008). Knowledge sharing ambidexterity in long-term interorganizational relationships. Management Science, 54, 1281-1296.

Jansen, J. J. P., George, G., Van den Bosch, F. A. J., \& Volberda, H. W. (2008). Senior team attributes and organizational ambidexterity: The moderating role of transformational leadership. Journal of Management Studies, 45(5), 982-1007.

Jansen, J. J. P., Simsek, Z., \& Cao, Q. (2012). Ambidexterity and performance in multi-unit contexts: Cross-level moderating effects of structural and resource attributes. Strategic Management Journal, 33(11), 1286-1303.

Jansen, J. J. P., Tempelaar, M. P., Van den Bosch, F. A. J., \& Volberda, H. W. (2009). Structural differentiation and ambidexterity: The mediating role of integration mechanisms. Organization Science, 20(4), 797-811.

Jansen, J. J. P., Van den Bosch, F. A. J., \& Volberda, H. (2005). Managing potential and realized absorptive capacity: How do organizational antecedents matter? Academy of Management Journal, 48, 999-1015.

Jansen, J. J. P., Van den Bosch, F. A. J., \& Volberda, H. W. (2006). Exploratory innovation, exploitative innovation, and performance: Effects of organizational antecedents and environmental moderators. Management Science, 52, 1661-1674.

Jansen, J. J. P., Vera, D., \& Crossan, M. (2009). Strategic leadership for exploration and exploitation: The moderating role of environmental dynamism. The Leadership Quarterly, $20,5-18$.

Jasmand, C., Blazevic, V., \& de Ruyter, K. (2012). Generating sales while providing service: A study of customer service representatives' ambidextrous behavior. Journal of Marketing, 76(1), 20-37.

Jaworski, B. J., \& Kohli, A. K. (1993). Market orientation: Antecedents and consequences. Journal of Marketing, 57(7), 53-70.

Joshi, A., \& Giménez, E. (2014). Decision-driven marketing. Harvard Business Review, 92(7/8), 64-71.

Judge, W. Q., \& Blocker, C. P. (2008). Organizational capacity for change and strategic ambidexterity: Flying the plane while rewiring it. European Journal of Marketing, 42(9/10), 915-926.

Junni, P., Sarala, R. M., Taras, V., \& Tarba, S. Y. (2013). Organizational ambidexterity and performance: A meta-analysis. Academy of Management Perspectives, 27(4), 299-312.

Junni, P., Sarala, R. M., Tarba, S. Y., Liu, Y., \& Cooper, C. L. (2015). Guest editors' introduction: The role of human resources and organizational factors in ambidexterity. Human Resource Management, 54(S1), S1-S28.

Kang, S.-C., \& Snell, S. A. (2009). Intellectual capital architectures and ambidextrous learning: A framework for human resource management. Journal of Management Studies, 46(1), 65-92.

Kauppila, O. P. (2010). Creating ambidexterity by integrating and balancing separate interorganizational partnerships. Strategic Organization, 8, 283-312.

Kim, N. and Atuahene-Gima, K. (2010). Using exploratory and exploitative market learning for new product development. Journal of Product Innovation Management, 27(4), 519536.

Kimberly, J. R. (1979). Issues in the creation of organizations. Academy of Management Journal, 22, 437-457. 
Knott, A. M. (2002). Exploration and exploitation as complements. In C.W. Choo \& N. Bontis (Eds.), The strategic management of intellectual capital and organizational knowledge (pp. 339-358). New York: Oxford University Press.

Kyriakopoulos, K., \& Moorman, C. (2004). Tradeoffs in marketing exploitation and exploration strategies: The overlooked role of market orientation. International Journal of Research in Marketing, 21, 219-240.

Kyriakopoulos, K., Hughes, M., \& Hughes, P. (2016). The role of marketing resources in radical innovation activity: Antecedents and payoffs. Journal of Product Innovation Management, 33(4), 398-417.

Lant, T. K., \& Mezias, S. J. (1992). An organizational learning model of convergence and reorientation. Organization Science, 3(1), 47-71.

Lavie, D., \& Rosenkopf, L. (2006). Balancing exploration and exploitation in alliance formation. Academy of Management Journal, 49(4), 797-818.

Lavie, D., Kang, J., \& Rosenkopf, L. (2009). The performance effects of balancing exploration and exploitation within and across alliance domains. Paper presented at the Academy of Management Best Paper Proceedings, Chicago.

Lavie, D., Stettner, U., \& Tushman, M. L. (2010). Exploration and exploitation within and across organizations. Academy of Management Annals, 4(1), 109-155.

Lawrence, P. R., \& Lorsch, J. W. (1967). Differentiation and integration in complex organizations. Administrative Science Quarterly, 12, 1-47.

Leonard-Barton. D. (1992). Core capabilities and core rigidities: A paradox in managing new product development. Strategic Management Journal, 13(5), 111-125.

Levinthal, D. A., \& March, J. G. (1993). The myopia of learning. Strategic Management Journal, 14, 95-112.

Levitt, B., \& March, J. G. (1988). Organizational learning. Annual Review of Sociology, 14, 319-340.

Li, C.-R., Lin, C.-J., \& Chu, C.-P. (2008). The nature of market orientation and the ambidexterity of innovations. Management Decision, 46(7), 1002-1026.

Lin, H.-E., McDonough III, E. F., Lin, S.-J., \& Lin, C. Y.-Y. (2013). Managing the exploitation/exploration paradox: The role of a learning capability and innovation ambidexterity. Journal of Product Innovation Management, 30(2), 262-278.

Lubatkin, M. H., Simsek, Z., Ling, Y., \& Veiga, J. F. (2006). Ambidexterity and performance in small-to-medium-sized firms: The pivotal role of top management team behavioral integration. Journal of Management, 32(5), 646-672.

Luo, X., \& Donthu, N. (2006). Marketing's credibility: A longitudinal study of marketing communication productivity and shareholder value. Journal of Marketing, 70(October), 70-91.

Madhavaram, S., \& Hunt, S. D. (2008). The service-dominant logic and a hierarchy of operant resources: Developing masterful operant resources and implications for marketing strategy. Journal of the Academy of Marketing Science, 36(1), 67-82.

March, J. G. (1991). Exploration and exploitation in organizational learning. Organization Science, 2, 71-87.

March, J. G. (1999). The pursuit of organizational intelligence. Oxford: Blackwell.

March, J. G. (2006). Rationality, foolishness, and adaptive intelligence. Strategic Management Journal, 27, 201-214.

Menguc, B., \& Auh, S. (2008). The asymmetric effect of ambidexterity on firm performance for prospectors and defenders: The moderating role of marketing orientation. Industrial Marketing Management, 37, 455-470.

Miller, D., \& Friesen, P. H. (1980). Momentum and revolution in organizational adaptation. Academy of Management journal, 23(4), 591-614. 
Miller, D., \& Friesen, P. H. (1983). Strategy-making and environment: The third link. Strategic Management Journal, 4(3), 221-235.

Miller, D., \& Friesen, P. (1984). Organizations: A quantum view. Englewood Cliffs, NJ: Prentice-Hall.

Mintzberg, H. (1979). The structuring of organizations. Englewood Cliffs, NJ: Prentice Hall.

Mitchell, W., \& Singh, K. (1993). Death to the lethargic: Effects of expansion into new technical subfields on performance in a firm's base business. Organization Science, 4, $152-180$.

Mom, T. J. M., Van den Bosch, F. A. J., \& Volberda, H. W. (2009). Understanding variation in managers' ambidexterity: Investigating direct and interaction effects of formal structural and personal coordination mechanisms. Organization Science, 20(4), 812-828.

Morgan, R. E., \& Berthon, P. (2008). Market orientation, generative learning, innovation strategy and business performance inter-relationships in bioscience firms. Journal of Management Studies, 45(8), 1329-1353.

Nobeoka, K., \& Cusumano, M. A. (1998). Multiproduct strategy and sales growth: The benefits of rapid design transfer in new product development. Strategic Management Journal, 18, 169-186.

Nosella, A., Cantarello, S., \& Filippini, R. (2012). The intellectual structure of organizational ambidexterity: A bibliographic investigation into the state of the art. Strategic Organization, 10(4), 450-465.

Ocasio, W. (1997). Towards an attention-based view of the firm. Strategic Management Journal, 18(S1), 187-206.

O'Reilly, C. A., \& Tushman, M. L. (2004). The ambidextrous organization. Harvard Business Review, 82(4), 74-81.

O’Reilly, C. A., \& Tushman, M. L. (2008). Ambidexterity as a dynamic capability: Resolving the innovator's dilemma. Research in Organizational Behavior, 28, 185-206.

O'Reilly, C. A., \& Tushman, M. L. (2013). Organizational ambidexterity: Past, present, and future. Academy of Management Perspectives, 27(4), 324-338.

Osigweh, C.A.B. (1989). Concept fallibility in organizational science. Academy of Management Review, 14(4), 579-594.

Piao, M. (2010). Thriving in the new: Implication of exploration on organizational longevity. Journal of Management, 36, 1529-1554.

Prange, C., \& Schlegelmilch, B. B. (2009). The Role of ambidexterity in marketing strategy implementation: Resolving the exploration-exploitation dilemma. BuR - Business Research, 2(2), 214-240.

Quinn, R. E., \& Cameron, K. (1983). Organizational life cycles and shifting criteria of effectiveness: Some preliminary evidence. Management Science, 29(1), 33-51.

Raisch, S., \& Birkinshaw, J. (2008). Organizational ambidexterity: Antecedents, outcomes, and moderators. Journal of Management, 34(3), 375-409.

Reid, S. E., \& de Brentani, U. (2010). Market vision and market visioning competence: Impact on early performance for radically new, high-tech products. Journal of Product Innovation Management, 27(4), 500-518.

Rivkin, J. W., \& Siggelkow, N. (2003). Balancing search and stability: Interdependencies among elements of organizational design. Management Science, 49(3), 290-311.

Roberts, D., \& Candi, M. (2014). Leveraging social networks sites in new product development: Opportunity or Hype? Journal of Product Innovation Management, 31(S1), 105-117.

Roberts, D., Candi, M., \& Hughes, M. (2017). Leveraging social network sites for new product launch. Industrial Management \& Data Systems, forthcoming. 
Roberts, D., Hughes, M., \& Kertbo, K. (2014). Exploring consumers' motivations to engage in innovation through co-creation activities. European Journal of Marketing, 48(1), $147-$ 169.

Roberts, D., Piller, F. T., \& Luttgens, D. (2016). Mapping the impact of social media for innovation: The role of social media in explaining innovation performance in the PDMA comparative performance study. Journal of Product Innovation Management, 33, 117135.

Romanelli, E., \& Tushman, M. L. (1994). Organizational transformation as punctuated equilibrium: An empirical test. Academy of Management Journal, 37(5), 1141-1166.

Rosenkopf, L., \& Nerkar, A. (2001). Beyond local search: Boundary-spanning, exploration, and impact in the optical disk industry. Strategic Management Journal, 22, 287-306.

Rosing, K., Frese, M., \& Bausch, A. (2011). Explaining the heterogeneity of the leadershipinnovation relationship: Ambidextrous leadership. The Leadership Quarterly, 22, 956974.

Shane, S. (2003). A general theory of entrepreneurship: The individual-opportunity nexus. Northampton, MA: Edward Elgar.

Sidhu, J., Volberda, H., \& Commandeur, H. (2004). Exploring exploration orientation and its determinants: Some empirical evidence. Journal of Management Studies, 41, 913-932.

Siggelkow, N., \& Levinthal, D. A. (2003). Temporarily divide to conquer: Centralized, decentralized, and reintegrated organizational approaches to exploration and adaptation. Organization Science, 14(6), 650-669.

Siggelkow, N., \& Rivkin, J. (2005). Speed and search: Designing organizations for turbulence and complexity. Organization Science, 16, 101-122.

Simon, H. (1962). The architecture of complexity. Proceedings of the American Philosophical Society, 106(6), 467-482.

Simsek, Z. (2009). Organizational ambidexterity: Towards a multilevel understanding. Journal of Management Studies, 46(4), 597-624.

Simsek, Z., Heavey, C., Veiga, J. F., \& Souder, D. (2009). A typology for aligning organizational ambidexterity's conceptualizations, antecedents, and outcomes. Journal of Management Studies, 46(5): 864-894.

Sine, W. D., Mitsuhashi, H., \& Kirsch, D. A. (2006). Revisiting Burns and Stalker: Formal structure and new venture performance in emerging economic sectors. Academy of Management Journal, 49, 121-132.

Slater, S. F., Mohr, J. J., \& Sengupta, S. (2014). Radical product innovation capability: Literature review, synthesis, and illustrative research propositions. Journal of Product Innovation Management, 31(3), 552-566.

Smith, W. K., \& Tushman, M. L. (2005). Managing strategic contradictions: A top management model for managing innovation streams. Organization Science, 16(5), 522 536.

Stinchcombe, A. (1965). Social structure and organizations. In J. G. March (Ed), Handbook of organizations (pp. 142-193). Chicago: Rand McNally.

Stadler, C., Rajwani, T., \& Karaba, F. (2014). Solutions to the exploration/exploitation dilemma: Networks as a new level of analysis. International Journal of Management Reviews, 16, 172-193.

Stettner, U., \& Lavie, D. (2014). Ambidexterity under scrutiny: Exploration and exploitation via internal organization, alliances, and acquisitions. Strategic Management Journal, 35, 1903-1929.

Swart, J., \& Kinnie, N. (2007). Simultaneity of learning orientations in a marketing agency. Management Learning, 38, 337-357. 
Takeuchi, H., Osono, E., \& Shimizu, N. (2008). The contradictions that drive Toyota's success. Harvard Business Review, 86(6), 96-104.

Taylor, A., \& Helfat, C. (2009). Organizational linkages for surviving technological change: Complementary assets, middle management, and ambidexterity. Organization Science, 20(4), 718-739.

Thompson, J. D. (1967). Organizations in action: Social sciences bases of administrative theory. New York: McGraw-Hill.

Tushman, M. L., \& O’Reilly, C. A. (1996). Ambidextrous organizations: Managing evolutionary and revolutionary change. California Management Review, 38(4), 8-30.

Tushman, M. L., \& O'Reilly, C. A. (2002). Winning through innovation: A practical guide to leading organizational change and renewal. Boston, MA: Harvard University Press.

Tushman, M., \& Romanelli, E. (1985). Organizational evolution: A metamorphosis model of convergence and reorientation. In L. L. Cummings \& B. M. Staw (Eds.), Research in organizational behavior, vol. 7 (pp. 171-222). Greenwich, CT: JAI Press.

Uotila, J., Maula, M., Keil, T., \& Zhara, S. A. (2008). Exploration, exploitation and firm performance: An analysis of S\&P 500 corporations. Strategic Management Journal, 30, 221-231.

Van de Ven, A. H., \& Poole, M. S. (1995). Explaining development and change in organizations. Academy of Management Review, 20, 510-540.

Van Looy, B., Martens, T., \& Debackere, K. (2005). Organizing for continuous innovation: On the sustainability of ambidextrous organizations. Creativity and Innovation Management, 14, 208-221.

Vargo, S. L., \& Lusch, R. F. (2004). Evolving to a new dominant logic for marketing. Journal of Marketing, 68, 1-17.

Vargo, S. L., and Lusch, R. F. (2006). Service-dominant logic: What it is, what it is not, what it might be. In R. F. Lusch \& S. L. Vargo (Eds.), The service-dominant logic of marketing: Dialog, debate, and directions (pp. 43-57).New York: M.E. Sharpe.

Verhoef, P. C., \& Leeflang, P. S. H. (2009). Understanding the marketing department's influence within the firm. Journal of Marketing, 73(March), 14-37.

Volberda, H., Baden-Fuller, C., \& Van den Bosch, F. A. J. (2001). Mastering strategic renewal: Mobilizing renewal journeys in multi-unit firms. Long Range Planning, 34, 159178.

Vorhies, D. W., Orr, L. M., \& Bush, V. D. (2011). Improving customer-focused marketing capabilities and firm financial performance via marketing exploration and exploitation. Journal of the Academy of Marketing Science, 39, 736-756.

Voss, G. B., \& Voss, Z. G. (2013). Strategic ambidexterity in small and medium-sized enterprises: Implementing exploration and exploitation in product and market domains. Organization Science, 24(5), 1459-1477.

Voss, G. B., Sirdeshmukh, D., \& Voss, Z. G. (2008). The effects of slack resources and environmental threat on product exploration and exploitation. Academy of Management Journal, 51(1), 147-164.

Wang, H., \& Li, J. (2008). Untangling the effects of overexploration and overexploitation on organizational performance: The moderating role of organizational dynamism. Journal of Management, 34, 925-951.

Whitler, K. A., \& Morgan, N. A. (2017). Why CMOs never last and what to do about it. Harvard Business Review, 95(4), 46-54.

Woodward, J. (1965). Industrial organization: Theory and practice. New York: Oxford University Press. 
Xie, C. Y., Bagozzi, R. P., \& Troye, S. V (2008). Trying to prosume: Ttoward a theory of consumers as co-creators of value. Journal of the Academy of Marketing Science, 36(1), 109-122.

Yalcinkaya, G., Calantone, R. J., \& Griffith, D. A. (2007). An examination of exploration and exploitation capabilities: Implications for product innovation and market performance. Journal of International Marketing, 15(4), 63-93.

Yukl, G. (2009). Leading organizational learning: Reflections on theory and research. The Leadership Quarterly, 20(1), 49-53. 
Table 1: Definitions and Treatment of Organizational Ambidexterity in Organization and Management Studies

\begin{tabular}{|c|c|c|c|c|c|c|}
\hline Author(s) & Type & $\begin{array}{l}\text { Level(s) of } \\
\text { analysis }\end{array}$ & $\begin{array}{l}\text { Unit(s) of } \\
\text { analysis }\end{array}$ & $\begin{array}{l}\text { Subject of } \\
\text { ambidexterity }\end{array}$ & Definition & Elements \\
\hline $\begin{array}{l}\text { Duncan } \\
(1976)\end{array}$ & Theoretical & Business unit & $\begin{array}{l}\text { Organizational } \\
\text { structure; } \\
\text { innovation }\end{array}$ & $\begin{array}{l}\text { Initiation and } \\
\text { implementation }\end{array}$ & $\begin{array}{l}\text { Capacity of organizations to facilitate the differentiation } \\
\text { of organization structure that facilitates the innovation } \\
\text { process in its two different stages (initiation and } \\
\text { implementation). More specifically, the ability of the } \\
\text { organizational unit to deal with conflict, conduct } \\
\text { effective interpersonal relations, develop switching rules, } \\
\text { and institutionalize dual organizational structures for } \\
\text { innovation. }\end{array}$ & Simultaneity \\
\hline $\begin{array}{l}\text { Adler et al. } \\
\text { (1999) }\end{array}$ & Empirical & Business unit & $\begin{array}{l}\text { Routines; } \\
\text { flexibility and } \\
\text { efficiency }\end{array}$ & $\begin{array}{l}\text { Routine and } \\
\text { nonroutine }\end{array}$ & $\begin{array}{l}\text { The challenge of simultaneously performing both routine } \\
\text { and nonroutine tasks. }\end{array}$ & Simultaneity \\
\hline $\begin{array}{l}\text { Gibson and } \\
\text { Birkinshaw } \\
\text { (2004) }\end{array}$ & Empirical & Business unit & $\begin{array}{l}\text { Organizational } \\
\text { context and } \\
\text { design }\end{array}$ & $\begin{array}{l}\text { Alignment and } \\
\text { adaptability }\end{array}$ & $\begin{array}{l}\text { (Contextual) Ambidexterity is the behavioral capacity to } \\
\text { simultaneously demonstrate alignment and adaptability } \\
\text { across an entire business unit. Alignment refers to } \\
\text { coherence among all the patterns of activities in the } \\
\text { business unit; they are working together toward the same } \\
\text { goals. Adaptability refers to the capacity to reconfigure } \\
\text { activities in the business unit quickly to meet changing }\end{array}$ & Simultaneity \\
\hline
\end{tabular}




\begin{tabular}{|c|c|c|c|c|c|c|}
\hline & & & & & $\begin{array}{l}\text { demands in the task environment. } \\
\text { The ambidextrous organization achieves alignment in its } \\
\text { current operations while also adapting effectively to } \\
\text { changing environmental demands. }\end{array}$ & \\
\hline $\begin{array}{l}\text { He and } \\
\text { Wong (2004) }\end{array}$ & Empirical & Firm & Innovation & $\begin{array}{l}\text { Exploration } \\
\text { and } \\
\text { exploitation }\end{array}$ & $\begin{array}{l}\text { Drawing on Tushman and O'Reilly (1996): The need for } \\
\text { an appropriate balance between exploration and } \\
\text { exploitation... an ambidextrous firm that has the } \\
\text { capabilities to both compete in mature markets (where } \\
\text { cost, efficiency, and incremental innovation are critical) } \\
\text { and develop new products and services for emerging } \\
\text { markets (where experimentation, speed, and flexibility } \\
\text { are critical). }\end{array}$ & $\begin{array}{l}\text { Trade-off and } \\
\text { balance }\end{array}$ \\
\hline $\begin{array}{l}\text { Jansen et al. } \\
(2006)\end{array}$ & Empirical & Business unit & Innovation & $\begin{array}{l}\text { Exploration } \\
\text { and } \\
\text { exploitation }\end{array}$ & $\begin{array}{l}\text { Ambidextrous organizations develop exploratory and } \\
\text { exploitative innovation simultaneously in different } \\
\text { organizational units... [and must] coordinate the } \\
\text { development of exploratory and exploitative innovation } \\
\text { in organizational units. }\end{array}$ & Simultaneity \\
\hline $\begin{array}{l}\text { Gupta et al. } \\
(2006)\end{array}$ & Theoretical & $\begin{array}{l}\text { Firm, but } \\
\text { acknowledges } \\
\text { individual } \\
\text { and business } \\
\text { unit levels of } \\
\text { analyses }\end{array}$ & Learning & $\begin{array}{l}\text { Exploration } \\
\text { and } \\
\text { exploitation }\end{array}$ & $\begin{array}{l}\text { Ambidexterity refers to the synchronous pursuit of both } \\
\text { exploration and exploitation via loosely coupled and } \\
\text { differentiated subunits or individuals, each of which } \\
\text { specializes in either exploration or exploitation. }\end{array}$ & $\begin{array}{l}\text { Punctuated } \\
\text { equilibrium, } \\
\text { Synchronicity }\end{array}$ \\
\hline $\begin{array}{l}\text { Lubatkin et } \\
\text { al. (2006) }\end{array}$ & Empirical & Firm & Innovation & $\begin{array}{l}\text { Exploration } \\
\text { and } \\
\text { exploitation }\end{array}$ & $\begin{array}{l}\text { Firms capable of exploiting existing competencies as } \\
\text { well as exploring new opportunities with equal dexterity. }\end{array}$ & Dexterity \\
\hline $\begin{array}{l}\text { Bierly and } \\
\text { Daly (2007) }\end{array}$ & Empirical & Firm & $\begin{array}{l}\text { Knowledge } \\
\text { strategies }\end{array}$ & $\begin{array}{l}\text { Exploration } \\
\text { and } \\
\text { exploitation }\end{array}$ & Simultaneously excelling at exploration and exploitation. & $\begin{array}{l}\text { Simultaneity, } \\
\text { Dexterity }\end{array}$ \\
\hline $\begin{array}{l}\text { Raisch and } \\
\text { Birkinshaw } \\
(2008)\end{array}$ & $\begin{array}{l}\text { Literature } \\
\text { review }\end{array}$ & Not specified & $\begin{array}{l}\text { Many } \\
\text { including } \\
\text { organizational } \\
\text { learning, } \\
\text { technological }\end{array}$ & $\begin{array}{l}\text { Mixed: } \\
\text { exploration and } \\
\text { exploitation; } \\
\text { alignment and } \\
\text { adaptability; }\end{array}$ & $\begin{array}{l}\text { Similar to themes in Gibson and Birkinshaw (2004): } \\
\text { Successful firms are ambidextrous-aligned and efficient } \\
\text { in their management of today's business demands while } \\
\text { simultaneously adaptive to changes in the environment. }\end{array}$ & Simultaneity \\
\hline
\end{tabular}




\begin{tabular}{|c|c|c|c|c|c|c|}
\hline & & & $\begin{array}{l}\text { innovation, } \\
\text { organizational } \\
\text { adaptation, } \\
\text { strategic } \\
\text { management } \\
\text { and } \\
\text { organizational } \\
\text { design }\end{array}$ & $\begin{array}{l}\text { incremental } \\
\text { and } \\
\text { discontinuous }\end{array}$ & $\begin{array}{l}\text { Following Tushman and O'Reilly (1996): Ambidexterity } \\
\text { can be defined as a firm's ability to operate complex } \\
\text { organizational designs that provide for short-term } \\
\text { efficiency and long-term innovation. }\end{array}$ & \\
\hline $\begin{array}{l}\text { Andriopoulos } \\
\text { and Lewis } \\
(2009)\end{array}$ & Empirical & Firm & Innovation & $\begin{array}{l}\text { Incremental } \\
\text { and radical }\end{array}$ & $\begin{array}{l}\text { Ambidextrous organizations excel at exploiting existing } \\
\text { products to enable incremental innovation and at } \\
\text { exploring new opportunities to foster more radical } \\
\text { innovation.... yet tensions emanate from their different } \\
\text { knowledge management processes. Organizational } \\
\text { ambidexterity signifies a firm's ability to manage these } \\
\text { tensions. }\end{array}$ & $\begin{array}{l}\text { Trade-off and } \\
\text { balance, } \\
\text { Dexterity, } \\
\text { Managing } \\
\text { tension }\end{array}$ \\
\hline $\begin{array}{l}\text { Cao et al. } \\
(2009)\end{array}$ & Empirical & Firm & Innovation & $\begin{array}{l}\text { Exploration } \\
\text { and } \\
\text { exploitation }\end{array}$ & $\begin{array}{l}\text { The general agreement in this literature is that an } \\
\text { ambidextrous firm is one that is capable of both } \\
\text { exploiting existing competencies as well as exploring } \\
\text { new opportunities, and also that achieving ambidexterity } \\
\text { enables a firm to enhance its performance and } \\
\text { competitiveness... there exists a broad consensus among } \\
\text { definitions of ambidexterity that it somehow relates to } \\
\text { the simultaneous pursuit of exploration and exploitation. }\end{array}$ & $\begin{array}{l}\text { Simultaneity, } \\
\text { Trade-off and } \\
\text { balance, } \\
\text { Magnitude }\end{array}$ \\
\hline $\begin{array}{l}\text { Simsek } \\
(2009)\end{array}$ & $\begin{array}{l}\text { Theoretical } \\
\text { analysis and } \\
\text { literature } \\
\text { review }\end{array}$ & Firm & Learning & $\begin{array}{l}\text { Exploration } \\
\text { and } \\
\text { exploitation }\end{array}$ & $\begin{array}{l}\text { Extending March's (1991) discussion of exploitation and } \\
\text { exploration: We view OA [organizational ambidexterity] } \\
\text { as an organization-level construct that manifests itself in } \\
\text { the organization's exploitative and exploratory } \\
\text { attainments... adopting the organization as the unit of } \\
\text { analysis also helps to differentiate OA from constructs } \\
\text { such as structural ambidexterity (Benner and Tushman, } \\
\text { 2003) and contextual ambidexterity (Gibson and } \\
\text { Birkinshaw, 2004) that refer to the methods, practices, } \\
\text { and processes that an organization uses to attain OA. }\end{array}$ & $\begin{array}{l}\text { Dexterity, } \\
\text { Magnitude }\end{array}$ \\
\hline $\begin{array}{l}\text { Nosella et al. } \\
(2012)\end{array}$ & $\begin{array}{l}\text { Bibliographic } \\
\text { analysis }\end{array}$ & Firm & $\begin{array}{l}\text { Organizational } \\
\text { structure and }\end{array}$ & $\begin{array}{l}\text { Exploration } \\
\text { and }\end{array}$ & $\begin{array}{l}\text { Firms today increasingly have to deal with contrasting } \\
\text { and conflicting goals such as incremental vs. radical }\end{array}$ & $\begin{array}{l}\text { Magnitude, } \\
\text { Managing }\end{array}$ \\
\hline
\end{tabular}




\begin{tabular}{|c|c|c|c|c|c|c|}
\hline & & & design & exploitation & $\begin{array}{l}\text { innovation, exploration vs. exploitation (March, 1991), } \\
\text { alignment vs. adaptability (Gibson and Birkinshaw, } \\
\text { 2004), and many others. Understanding and managing } \\
\text { tensions as well as succeeding in simultaneously } \\
\text { accomplishing high levels of both the poles causing such } \\
\text { tensions are essential to firms' competitiveness and } \\
\text { survival (O'Reilly and Tushman, 2004, 2008). } \\
\text { Organizations able to do so possess the ambidexterity } \\
\text { capability, namely the capability of a complex and } \\
\text { adaptive system to achieve and manage conflicting } \\
\text { activities, by realizing high levels of both in a } \\
\text { simultaneous way. }\end{array}$ & $\begin{array}{l}\text { tension, Firm } \\
\text { survival }\end{array}$ \\
\hline $\begin{array}{l}\text { Birkinshaw } \\
\text { and Gupta } \\
(2013)\end{array}$ & Symposium & Firm & $\begin{array}{l}\text { Generally } \\
\text { addresses } \\
\text { situations of } \\
\text { competing } \\
\text { activities or } \\
\text { objectives }\end{array}$ & $\begin{array}{l}\text { Mixed: } \\
\text { exploration and } \\
\text { exploitation; } \\
\text { alignment and } \\
\text { adaptability }\end{array}$ & $\begin{array}{l}\text { Ambidexterity is an organization's capacity to address } \\
\text { two organizationally incompatible objectives equally } \\
\text { well. }\end{array}$ & $\begin{array}{l}\text { Trade-off and } \\
\text { balance, } \\
\text { Managing } \\
\text { tension }\end{array}$ \\
\hline $\begin{array}{l}\text { Junni et al. } \\
(2013)\end{array}$ & $\begin{array}{l}\text { Meta- } \\
\text { analysis }\end{array}$ & Multiple & $\begin{array}{l}\text { Did not } \\
\text { differentiate } \\
\text { according to } \\
\text { the focus or } \\
\text { subject } \\
\text { exploration or } \\
\text { exploitation } \\
\text { might take, } \\
\text { but their } \\
\text { definition } \\
\text { spoke to } \\
\text { innovation }\end{array}$ & $\begin{array}{l}\text { Mixed: } \\
\text { exploration and } \\
\text { exploitation; } \\
\text { incremental } \\
\text { and } \\
\text { discontinuous }\end{array}$ & $\begin{array}{l}\text { Adopted O'Reilly and Tushman (2004): Organizational } \\
\text { ambidexterity is defined as the ability of an organization } \\
\text { to simultaneously pursue both explorative } \\
\text { (discontinuous) and exploitative (incremental) } \\
\text { innovation. }\end{array}$ & $\begin{array}{l}\text { Simultaneity, } \\
\text { Managing } \\
\text { tension }\end{array}$ \\
\hline
\end{tabular}

Fundamental recurring elements: (1) simultaneity versus punctuation, (2) trade-off and balance, (3) synchronicity and dexterity, (4) magnitude, (5) managing tension, (6) firm survival. 
Table 2: Treatment of Organizational Ambidexterity among Marketing-related Studies

\begin{tabular}{|c|c|c|c|c|c|c|c|}
\hline Author(s) & Type & $\begin{array}{l}\text { Level(s) } \\
\text { of } \\
\text { analysis }\end{array}$ & $\begin{array}{l}\text { Unit(s) of } \\
\text { analysis }\end{array}$ & $\begin{array}{l}\text { Subject of } \\
\text { ambidexterity }\end{array}$ & $\begin{array}{l}\text { Aspect of } \\
\text { marketing } \\
\text { addressed }\end{array}$ & Definition & $\begin{array}{l}\text { Treatment versus } \\
\text { fundamental elements of } \mathrm{OA}\end{array}$ \\
\hline $\begin{array}{l}\text { Kyriakopoulos } \\
\text { and Moorman } \\
\text { (2004) }\end{array}$ & Empirical & $\begin{array}{l}\text { Business } \\
\text { unit }\end{array}$ & $\begin{array}{l}\text { Marketing } \\
\text { strategy }\end{array}$ & $\begin{array}{l}\text { Exploration } \\
\text { and } \\
\text { exploitation }\end{array}$ & $\begin{array}{l}\text { Market } \\
\text { orientation }\end{array}$ & $\begin{array}{l}\text { Firms should both exploit } \\
\text { and explore in order to } \\
\text { increase their chances of } \\
\text { long-term survival. }\end{array}$ & $\begin{array}{l}\text { Inconsistent: } \\
\text { Do not provide a clear } \\
\text { definition. Appear to follow } \\
\text { Levinthal and March (1993): } \\
\text { The basic problem confronting } \\
\text { an organization is to engage in } \\
\text { sufficient exploitation to } \\
\text { ensure its current viability and, } \\
\text { at the same time, to devote } \\
\text { enough energy to exploration } \\
\text { to ensure its future viability. } \\
\text { Survival requires a balance, } \\
\text { and the precise mix of } \\
\text { exploitation and exploration } \\
\text { that is optimal is hard to } \\
\text { specify. }\end{array}$ \\
\hline $\begin{array}{l}\text { Cegarra- } \\
\text { Navarro and } \\
\text { Dewhurst } \\
(2007)\end{array}$ & Empirical & Firm & Learning & $\begin{array}{l}\text { Alignment and } \\
\text { adaptability }\end{array}$ & $\begin{array}{l}\text { Customer } \\
\text { capital }\end{array}$ & $\begin{array}{l}\text { Ambidexterity is an } \\
\text { organization's context to } \\
\text { achieve alignment and } \\
\text { adaptability simultaneously } \\
\text { within the organization } \\
\text { learning processes. }\end{array}$ & Simultaneity \\
\hline $\begin{array}{l}\text { Swart and } \\
\text { Kinnie (2007) }\end{array}$ & Empirical & Firm & Learning & $\begin{array}{l}\text { Mixed: } \\
\text { exploration } \\
\text { and }\end{array}$ & $\begin{array}{l}\text { Learning in a } \\
\text { marketing } \\
\text { agency }\end{array}$ & $\begin{array}{l}\text { We define organizational } \\
\text { learning as the renewal and } \\
\text { refinement of strategic }\end{array}$ & $\begin{array}{l}\text { Inconsistent: } \\
\text { Implies simultaneity but form } \\
\text { and function of exploration }\end{array}$ \\
\hline
\end{tabular}




\begin{tabular}{|c|c|c|c|c|c|c|c|}
\hline & & & & $\begin{array}{l}\text { exploitation; } \\
\text { accelerated } \\
\text { and planned }\end{array}$ & & $\begin{array}{l}\text { knowledge assets which is } \\
\text { enabled through the } \\
\text { interaction or flow between } \\
\text { key knowledge assets. Both } \\
\text { modes of learning take place } \\
\text { concurrently within } \\
\text { accelerated/short-term and } \\
\text { planned/longer-term time } \\
\text { frames. }\end{array}$ & $\begin{array}{l}\text { and exploitation inconsistent } \\
\text { with theoretical assumptions } \\
\text { established in management } \\
\text { literature. }\end{array}$ \\
\hline $\begin{array}{l}\text { Yalcinkaya et } \\
\text { al. (2007) }\end{array}$ & Empirical & Firm & Capabilities & $\begin{array}{l}\text { Exploration } \\
\text { and } \\
\text { exploitation }\end{array}$ & $\begin{array}{l}\text { Marketing } \\
\text { resources, } \\
\text { market } \\
\text { performance }\end{array}$ & No clear definition provided. & $\begin{array}{l}\text { Inconsistent: } \\
\text { Predicted and found supporting } \\
\text { evidence for exploitation } \\
\text { capability being positively } \\
\text { related to an exploration } \\
\text { capability. This is } \\
\text { incompatible with March's } \\
1991 \text { trade-off arguments but } \\
\text { potentially compatible with } \\
\text { Gupta et al.'s } 2006 \\
\text { orthogonality arguments. } \\
\text { Theoretical treatment ignored } \\
\text { most fundamental elements of } \\
\text { OA. } \\
\text { Did not make predictions } \\
\text { about ambidexterity but } \\
\text { acknowledge that the literature } \\
\text { suggests that firms must } \\
\text { engage in the establishment } \\
\text { and development of both } \\
\text { capabilities for long-term } \\
\text { success. }\end{array}$ \\
\hline $\begin{array}{l}\text { Judge and } \\
\text { Blocker } \\
(2008)\end{array}$ & Theoretical & Firm & Strategy & $\begin{array}{l}\text { Exploration } \\
\text { and } \\
\text { exploitation }\end{array}$ & $\begin{array}{l}\text { Capacity for } \\
\text { change }\end{array}$ & $\begin{array}{l}\text { The ability to simultaneously } \\
\text { pursue exploitation and } \\
\text { exploratory strategies in }\end{array}$ & Simultaneity \\
\hline
\end{tabular}




\begin{tabular}{|c|c|c|c|c|c|c|c|}
\hline & & & & & & $\begin{array}{l}\text { ways that lead to enhanced } \\
\text { organizational effectiveness. }\end{array}$ & \\
\hline $\begin{array}{l}\text { Menguc and } \\
\text { Auh (2008) }\end{array}$ & Empirical & Firm & Innovation & $\begin{array}{l}\text { Exploration } \\
\text { and } \\
\text { exploitation }\end{array}$ & $\begin{array}{l}\text { Market } \\
\text { orientation }\end{array}$ & $\begin{array}{l}\text { The combination of two } \\
\text { discrete capabilities } \\
\text { (exploration and } \\
\text { exploitation). A firm's } \\
\text { higher-order capability of } \\
\text { simultaneously pursuing } \\
\text { competing, contradictory, } \\
\text { discrete capabilities... an } \\
\text { ambidextrous firm as one that } \\
\text { jointly pursues exploration } \\
\text { and exploitation. }\end{array}$ & Simultaneity \\
\hline $\begin{array}{l}\text { Morgan and } \\
\text { Berthon } \\
(2008)\end{array}$ & Empirical & $\begin{array}{l}\text { Business } \\
\text { unit }\end{array}$ & $\begin{array}{l}\text { Innovation } \\
\text { strategy }\end{array}$ & $\begin{array}{l}\text { Exploration } \\
\text { and } \\
\text { exploitation }\end{array}$ & $\begin{array}{l}\text { Market } \\
\text { orientation }\end{array}$ & $\begin{array}{l}\text { The ambidextrous association } \\
\text { between both forms of } \\
\text { innovation strategy } \\
\text { (explorative and exploitative } \\
\text { innovation strategy). }\end{array}$ & $\begin{array}{l}\text { Inconsistent: } \\
\text { Notion of association does not } \\
\text { specify the nature of that } \\
\text { combination. }\end{array}$ \\
\hline $\begin{array}{l}\text { Prange and } \\
\text { Schlegelmilch } \\
(2009)\end{array}$ & Empirical & Firm & Strategy & $\begin{array}{l}\text { Exploration } \\
\text { and } \\
\text { exploitation }\end{array}$ & $\begin{array}{l}\text { Marketing } \\
\text { strategy } \\
\text { implementation }\end{array}$ & $\begin{array}{l}\text { To balance the dual processes } \\
\text { of exploration and } \\
\text { exploitation... a conceptual } \\
\text { framework for implementing } \\
\text { inherently contradictory } \\
\text { marketing strategies. }\end{array}$ & Trade-off and balance \\
\hline $\begin{array}{l}\text { Hughes et al. } \\
(2010)\end{array}$ & Empirical & Firm & Innovation & $\begin{array}{l}\text { Exploration } \\
\text { and } \\
\text { exploitation }\end{array}$ & $\begin{array}{l}\text { Product-market } \\
\text { advantage }\end{array}$ & $\begin{array}{l}\text { Generating both explorative } \\
\text { and exploitative innovations } \\
\text { simultaneously through } \\
\text { [innovation] ambidexterity. }\end{array}$ & Simultaneity \\
\hline $\begin{array}{l}\text { Vorhies et al. } \\
\text { (2011) }\end{array}$ & Empirical & Firm & Marketing & $\begin{array}{l}\text { Exploration } \\
\text { and } \\
\text { exploitation }\end{array}$ & $\begin{array}{l}\text { Marketing } \\
\text { capabilities }\end{array}$ & $\begin{array}{l}\text { Firms that are able to } \\
\text { combine exploration and } \\
\text { exploitation in } \\
\text { complementary ways may } \\
\text { have a significant advantage } \\
\text { over those firms that are } \\
\text { unable to integrate }\end{array}$ & $\begin{array}{l}\text { Inconsistent: } \\
\text { Do not test ambidexterity in } \\
\text { and of itself. Predict that } \\
\text { marketing exploitation will } \\
\text { negatively moderate the effect } \\
\text { of marketing exploration on } \\
\text { customer-focused marketing }\end{array}$ \\
\hline
\end{tabular}




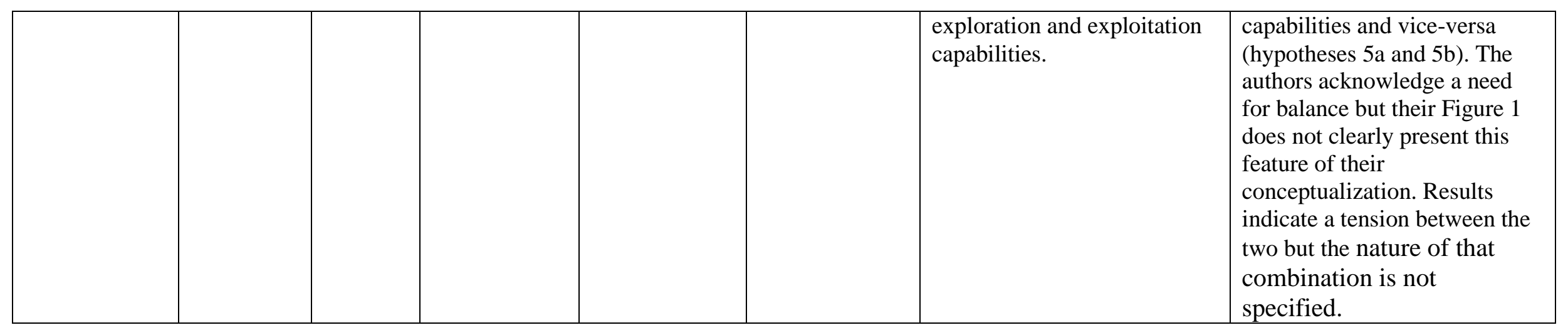


Table 3: Overview of Forms of Organizational Ambidexterity

\begin{tabular}{|c|c|c|c|c|}
\hline Form & Structural ambidexterity & Contextual ambidexterity & Temporal ambidexterity & $\begin{array}{l}\text { Specialization, and domain } \\
\text { ambidexterity }\end{array}$ \\
\hline Description & $\begin{array}{l}\text { Exploration and exploitation are } \\
\text { structurally separated into } \\
\text { different units that can specialise } \\
\text { each in each one separately. }\end{array}$ & $\begin{array}{l}\text { Exploration and exploitation are } \\
\text { deemed to be independent and } \\
\text { capable of being hosted (or } \\
\text { pursued) simultaneously within } \\
\text { a single firm or unit. }\end{array}$ & $\begin{array}{l}\text { Exploration and exploitation } \\
\text { activities occur in cyclical } \\
\text { periods, the precise timeframe } \\
\text { for which is undefined. The } \\
\text { firm cycles through episodes of } \\
\text { exploitation to exploration. }\end{array}$ & $\begin{array}{l}\text { A firm specialises in either } \\
\text { exploration or exploitation and } \\
\text { then allying with partners } \\
\text { capable of providing the } \\
\text { missing activity; or firms } \\
\text { balance exploration and } \\
\text { exploitation by exploring in one } \\
\text { domain but exploiting in } \\
\text { another. Networks may also be } \\
\text { used instead of alliances. }\end{array}$ \\
\hline Main features & $\begin{array}{l}\text { Structural separation overcomes } \\
\text { the tension caused by the trade-off } \\
\text { and irreconcilability between } \\
\text { exploration and exploitation, } \\
\text { allowing each to have its own } \\
\text { dedicated structures, processes, } \\
\text { systems and routines to optimise } \\
\text { that are multiple and } \\
\text { contradictory. } \\
\text { Structural separation calls for } \\
\text { coordination mechanisms to be } \\
\text { put in place to manage exploration } \\
\text { and exploitation simultaneously. }\end{array}$ & $\begin{array}{l}\text { As the name suggests, } \\
\text { contextual ambidexterity is } \\
\text { achieved by developing an } \\
\text { internal environment that allows } \\
\text { individuals to switch freely } \\
\text { between, or pursue } \\
\text { concurrently, exploration and } \\
\text { exploitation activities. } \\
\text { Internal organization } \\
\text { (organizational structure, } \\
\text { processes, culture and context) } \\
\text { must be managed to enable } \\
\text { ambidexterity. }\end{array}$ & $\begin{array}{l}\text { Cycling between exploitation } \\
\text { and exploration requires the } \\
\text { firm to be able to readily and } \\
\text { timely detect when the shift is } \\
\text { needed, and then dislodge the } \\
\text { internal pressures supporting } \\
\text { the current status quo. Periods } \\
\text { of exploitation are likely to be } \\
\text { longer than exploration. } \\
\text { The firm must then be adept at } \\
\text { managing transition and } \\
\text { changing its organizational } \\
\text { conditions to support either } \\
\text { activity as and when required. }\end{array}$ & $\begin{array}{l}\text { The tensions and resource } \\
\text { demands created by both } \\
\text { exploration and exploitation } \\
\text { meant that for some firms, } \\
\text { specialization might be better } \\
\text { for firm performance. } \\
\text { Firms can relax resource } \\
\text { constraints and circumvent } \\
\text { challenges in organising for and } \\
\text { coordinating exploration and } \\
\text { exploitation by specializing in } \\
\text { one and balancing the other in } \\
\text { within an alternative domain. }\end{array}$ \\
\hline $\begin{array}{l}\text { Exemplar } \\
\text { works }\end{array}$ & $\begin{array}{l}\text { Tushman and O'Reilly (1996) } \\
\text { O'Reilly and Tushman (2008) } \\
\text { Jansen et al. (2006, 2009) }\end{array}$ & $\begin{array}{l}\text { Adler et al. (1999) } \\
\text { Birkinshaw and Gibson (2004) } \\
\text { Gibson and Birkinshaw (2004) }\end{array}$ & $\begin{array}{l}\text { Gupta et al. (2006) } \\
\text { Lant and Mezias (1992) } \\
\text { Romanelli and Tushman (1994) } \\
\text { Siggelkow and Levinthal (2003) }\end{array}$ & $\begin{array}{l}\text { Gupta et al. (2006) } \\
\text { Lavie et al. (2010) } \\
\text { Lavie and Rosenkopf (2006) } \\
\text { Lavie, Kang and Rosenkopf } \\
\text { (2009) }\end{array}$ \\
\hline
\end{tabular}




\begin{tabular}{|l|l|l|l|l|}
\hline & & & $\begin{array}{l}\text { Stadler, Rajwani and Karaba } \\
(2014)\end{array}$ \\
\hline
\end{tabular}


Figure 1: Conceptual Model Containing the Theoretical Assumptions of Organizational Ambidexterity Theory

A-C Simultaneity assumption

\section{A. Trade-off \\ A1.1 High exploit $^{n} \neq$ High explor $^{n}$}

\section{B. Contextual}

B1.1 Independence

assumption

B1.2 High exploit $^{n}$ and high

explor ${ }^{n}$ possible)

\section{Dexterity}

C1.1 High exploit ${ }^{n}$ and high explorn $^{n}$

A-C Balance assumption
A1.2 Self-reinforcing logics

FORM OF ORGANIZATIONAL

A2 1 Resource intense A2.2 Irreconcilable

tensions

B2.1 Reconcilable tensions

B2.2 Organization-wide, avoiding coordination problems and costs

2.1 Tensions exist (as a starting point)

C2.2 (But) Assumption of high magnitude

C2.3 No research absorption assumption

D2.1 Cycles through period of exploitation and exploration

D2.2 Periods of exploitation are longer

D. Punctuated

D2.3 Certain degree of ease in

D1.1 Temporal, cyclical switching
D1.2 Time assumption
AMBIDEXTERITY

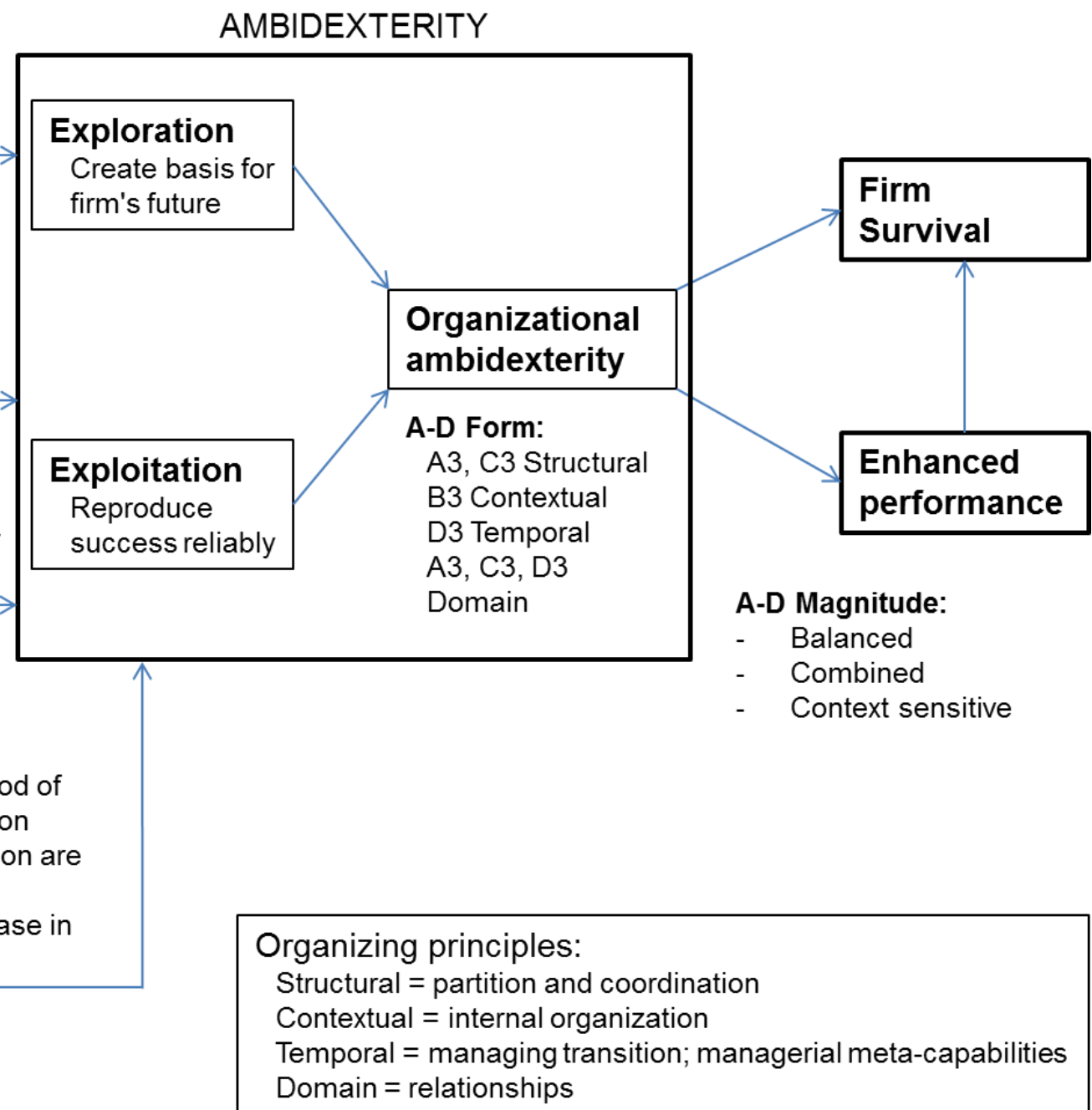

